\title{
Updates on Glucose 6-Phosphate Dehydrogenase (G6PD): From Prokaryotes to Human
}

\author{
Arolasafe Gbemisola J. ${ }^{1,2}$, Ibraheem Omodele ${ }^{3 *}$, Otohinoyi David A. ${ }^{4}$, Jeje Temitope $0 .^{3}$ \\ ${ }^{1}$ Department of Biological Sciences, Landmark University, PMB 1001 Omu-Aran, Kwara State, Nigeria \\ ${ }^{2}$ Department of Biomedical Informatics, Nova Southeastern University, 3301 College Avenue, Fort Lauderdale, Florida, USA \\ ${ }^{3}$ Department of Biochemistry, Federal University Oye-Ekiti, PMB 373, Oye-Ekiti, Ekiti State, Nigeria. \\ ${ }^{4}$ School of Medicine, All Saints University, Hillsbororough Street, P. O. Box 1679, Roseau Dominica \\ ${ }^{3}$ Department of Biochemistry, Federal University Oye-Ekiti, PMB 373, Oye-Ekiti, Ekiti State, Nigeria
}

\begin{abstract}
Glucose 6-phosphate dehydrogenase (G6PD) is the rate determining enzyme that catalyzes the first step in pentose phosphate pathway (PPP) which produces NADPH that serves as reducing agent for reductive biosynthetic reactions such as steroids, fatty acids and nucleotides syntheses. Been ubiquitous, it has been found in wide range of organisms, ranging from prokaryotic organisms to even higher animals like human. Numerous G6PD isoenzymes have been isolated, purified and well characterised. However, obtained information such as its kinetic parameters and biological properties have not been judiciously appropriated for biotechnological/medical applications. This review thus concisely showcases G6PD, focusing on some sources where it has been isolated, purified and characterized, physicochemical/biochemical properties, the benefits and adverse effects its evolution may confer, and the possible biotechnological applications/prospects for the enzyme.
\end{abstract}

Keywords: Anaemia, Haemoglobin, NADPH, Oxidative stress, Pentose Phosphate Pathway (PPP), Reactive Oxygen Species (ROS

\section{Introduction}

Enzymes are biochemical substance that mediate biochemical reactions by binding to specific substrates, enabling them to either slow down or increase the rate of reactions without been used up [1]. Also recognised as biological catalysts, they are classified as been proteinous with the exception of ribozymes. Enzymes can be categorized into six different classes, which include oxidoreductase, transferase, hydrolase, lyase, isomerase and ligase [1].

Glucose 6 phosphate dehydrogenase (G6PD; E.C. 1.1.1.49) belongs to the oxidoreductase classes of enzymes and are peculiar to Pentose Phosphate Pathway (also called the Hexose Monophosphate Shunt or the phosphogluconate pathway) [2, 3]. The Pentose Phosphate Pathway (PPP) is involved in the generation of reducing power, NADPH (reduced nicotinamide adenine dinucleotide phosphate), common to non-photosynthetic cells and organisms [2, 3]. This pathway is also involved in the synthesis of ribose 5phosphate which is highly essential for diving cells to produce RNA, DNA and coenzymes such as ATP, NADH and coenzyme $\mathrm{A}[2,3]$.

\subsection{Pentose Phosphate Pathway}

The Pentose Phosphate Pathway (Fig 1) provides an alternate route of carbohydrate catabolism to glycolysis [4]. The major difference between glycolysis and the Pentose Phosphate Pathway is that the latter produces only NADPH, whereas glycolysis generates NADH [5]. It is also found in all prokaryotes and eukaryotes, both heterotrophic and photosynthetic [6]. It is the pathway that supplies the majority of reducing power in form of NADPH for reductive biosynthesis. It consists of two stages:

- The oxidative phase; and,

- The non-oxidative (regenerative) phase

The first step of the oxidative phase, which is the limiting step, is catalysed by G6PD [4]. G6PD catalyses dehydrogenation of $\beta$-D-glucose 6 phosphate (G6P) at carbon 1, leading to the formation of 6phosphogluconolactone. This molecule is then hydrolysed by a lactonase to give 6-phosphogluconate. 6-phosphogluconate is oxidatively decarboxylated to form ribulose- 5 phosphate. In the first two steps, $\mathrm{NADP}^{+}$is the electron acceptor and as result, NADPH is produced. These NADPH molecules provide reducing power for the prevention of oxidative stress and for biosynthesis. Ribulose 5 phosphate is then isomerised to ribose 5 phosphate (R5P). This ribose 5 phosphate is used in nucleotide and nucleic acid synthesis. The oxidative phase which is well regulated and also irreversible produces two molecules of NADPH, one molecule of $\mathrm{CO}_{2}$ and ribulose 5 phosphate $[6,7,8]$.

In the non-oxidative phase, transaldolase and transketolase catalyse the inter-conversion of three, four, five, six and seven carbon sugars [8]. Carbon inputs may be recycled in the regenerative phase of the PPP and recycled back into the oxidative portion of the pathway, by the activity of hexose phosphate isomerase [9].The sugars are reversely converted into glucose 6 phosphate which starts the cycle all over again, making this stage the regenerative phase [10].

The expression of the reactions in PPP can be illustrated using the equation:

$\mathrm{G} 6 \mathrm{P}+2 \mathrm{NADP}^{+}+2 \mathrm{H}_{2} \mathrm{O} \rightarrow \mathrm{R} 5 \mathrm{P}+2 \mathrm{NADPH}+2 \mathrm{H}^{+}+\mathrm{CO}_{2}$ 


\section{International Journal of Science and Research (IJSR) \\ ISSN (Online): 2319-7064}

Index Copernicus Value (2013): 6.14 | Impact Factor (2013): 4.438

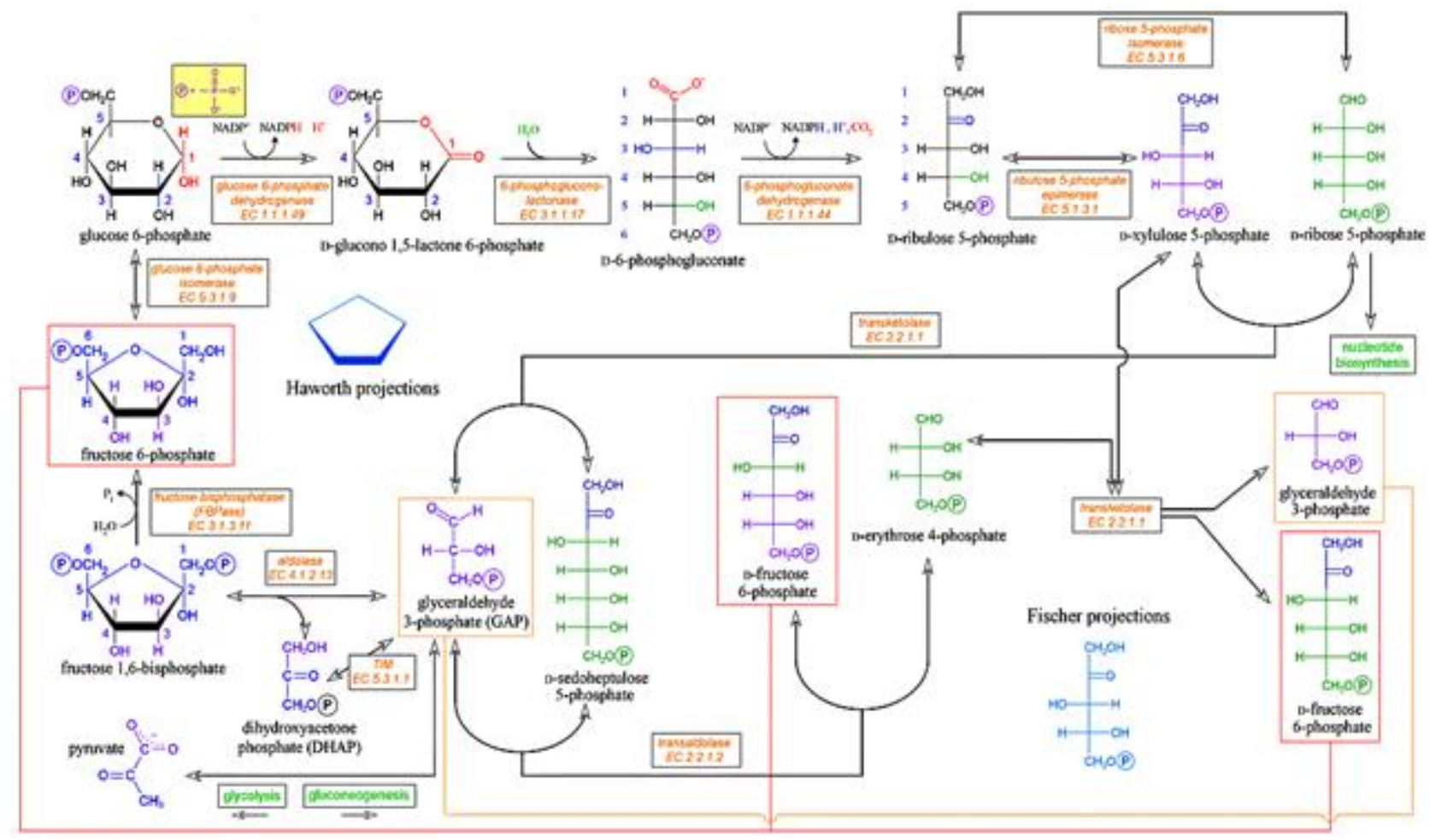

Figure 1: Pentose phosphate pathway. Adapted from Cronk [11]

\subsection{Glucose 6-Phosphate Dehydrogenase (G6PD)}

The entire antioxidant system is dependent on NADPH; as a result, the production of reduced gluthathione is dependent on the production of NADPH which is also overly dependent on G6PD activity. G6PD activity is induced during oxidative stress and is the only source of protection against oxidative stress in red blood cells $[12,13]$.

Aside from G6PD, other enzymes like isocitrate dehydrogenase, glutamate dehydrogenase and malic enzyme have also showed ability to produce NADPH in the mitochondria; however G6PD is the chief producer of NADPH [13]. There are many other systems dependent on NAPDH including enzymes involved in lipid production such as 3-hydroxy-3-methylglutaryl-CoA reductase and the NADPH-cytochrome P450 oxidoreductase that is required for drug metabolism, steroid biosynthesis, and many other functions [8].

G6PD is a cytosolic homeostatic enzyme that is encoded by a housekeeping X-linked gene, and the structural and functional features of G6PD promoter conform to those of a typical housekeeping gene [14]. The G6PD gene is present on the long arm of the X chromosome (Xq28) and consists of 13 exons with a length of $18 \mathrm{~kb}$. Its active form is either a dimer or a tetramer of a single polypeptide subunit of about $59 \mathrm{kD}[15]$.

Amongst the two molecule of NADPH produced during PPP, the first molecule reduces oxidized glutathione (GSSG) to reduced glutathione (GSH) which is used to prevent oxidative stress, while the second molecule provides reducing power for fatty acid metabolism, cholesterol and steroid hormones biosynthesis in the liver and other organs [12].

\subsection{Historical Background \& Distribution of Glucose 6- Phosphate Dehydrogenase}

D-G6PD (Zwischenferment) was first identified in 1931 by Warburg and Christian [16] in horse erythrocytes. It was characterised in 1962 by Kirkman and Henderickson in human erythrocytes [4]. By 1979, G6PD was isolated and characterised in red blood cells and yeast cells [3]. Ever since then it has been identified in various organisms ranging from prokaryotes to humans, including bacteria, algae, fungi and ferns. It is present in all cells, but its concentration varies in tissues [11]. Even with its ubiquitous nature, it was discovered that G6PD is absent in some microorganisms. This could be attributed to the fact that some organisms are not exposed to oxidative stress [14].

In animal tissues, G6PD is found in the mitochondria and cytosol and in plant tissues, it is found in the cytosol and chloroplast [17]. In mammals, it shows the highest activity in mammary glands, adipose tissues and the liver [13]. The increased activity in these organs and tissues is probably due to the fatty acid biosynthesis. Activity of this enzyme has also been discovered in the kidneys, though not as much as the abovementioned organs [18]. Some of the organisms that have been discovered to produce G6PD are shown in Table 1 . 
International Journal of Science and Research (IJSR)

ISSN (Online): 2319-7064

Index Copernicus Value (2013): 6.14 | Impact Factor (2013): 4.438

Table 1: Showing Sources of Identified and Characterised G6PD

\begin{tabular}{|c|c|c|c|c|c|}
\hline ORGANISMS & EXAMPLES & REFERENCE(S) & ORGANISMS & EXAMPLES & REFERENCE(S) \\
\hline BACTERIA & $\begin{array}{l}\text { Cyanobacteria anabaena } \\
\text { Escherichia coli } \\
\text { Leuconostoc mesenteroides } \\
\text { Bacilhus lichenformis } \\
\text { Acetobacter hensenni } \\
\text { Zymomonas mobilis } \\
\text { Azotobacter vinelandii } \\
\text { Corynebacterium glutamicum } \\
\text { Thermotoga maritima }\end{array}$ & $\begin{array}{l}{[19]} \\
{[20]} \\
{[21,22]} \\
{[23]} \\
{[18]} \\
{[24]} \\
{[25]} \\
{[26]} \\
{[27]}\end{array}$ & $\begin{array}{l}\text { HIGHER } \\
\text { PLANTS }\end{array}$ & $\begin{array}{l}\text { Plastidic stroma, cytosol and peroxisome } \\
\text { of higher plants } \\
\text { Spinach } \\
\text { Pea leaves } \\
\text { Tobacco } \\
\text { Wheat } \\
\text { Castor oil seeds } \\
\text { Potato tubers } \\
\text { Sycamore seeds and cauliflower buds }\end{array}$ & $\begin{array}{l}{[38]} \\
{[39]} \\
{[40,41]} \\
{[42]} \\
{[43]} \\
{[44]} \\
{[45]} \\
{[46,47]}\end{array}$ \\
\hline ALGAE & $\begin{array}{l}\text { Chlamydomonas reinhar ditii } \\
\text { Chlorella vulgar is }\end{array}$ & $\begin{array}{l}{[28]} \\
{[29]}\end{array}$ & INSECTS & $\begin{array}{l}\text { Plasmodium falciparum } \\
\text { Drosophila melanogaster }\end{array}$ & $\begin{array}{l}{[48]} \\
{[48]}\end{array}$ \\
\hline FUNGI & $\begin{array}{l}\text { Aspergillus aculeatus } \\
\text { Aspergillus niger } \\
\text { Aspergillus nidulans } \\
\text { Penicillum notatum } \\
\text { Penicillum dupontis } \\
\text { Aspergillus parasiticus } \\
\text { Neurospora crassa } \\
\text { Candida tropicalis } \\
\text { Agaricus biosporus }\end{array}$ & $\begin{array}{l}{[30]} \\
{[31]} \\
{[32]} \\
{[33]} \\
{[33]} \\
{[34]} \\
{[35]} \\
{[36]} \\
{[37]}\end{array}$ & MAMMALS & $\begin{array}{l}\text { Rabbit luminal endoplasmic reticulum } \\
\text { Mouse liver } \\
\text { Rat liver microsome } \\
\text { Dog liver } \\
\text { Pig liver and sheep lens } \\
\text { Buffalo erythrocytes } \\
\text { Bovine erythrocyte } \\
\text { Goat erythrocyte } \\
\text { Human erythrocyte }\end{array}$ & $\begin{array}{l}51] \\
{[53]} \\
{[54]} \\
{[55]} \\
{[13]} \\
{[56]} \\
{[57]} \\
{[58]} \\
{[9,59-64]}\end{array}$ \\
\hline FISH & $\begin{array}{l}\text { Rainbow trout liver } \\
\text { Lake van fish erythrocytes } \\
\text { Rainbow trout erythrocytes }\end{array}$ & $\begin{array}{l}499] \\
{[50]} \\
{[17]}\end{array}$ & BIRD & Chick brain & {$[52]$} \\
\hline
\end{tabular}

1.4 Purification and Characterisation of Glucose 6Phosphate Dehydrogenase

With the importance of G6PD in various organisms, more studies and experiments beyond the works of Warburg and Christian [65] have been carried out to further explain its structure and function (See Table 2 and 3).

Yoshida $[59,66]$ revealed that G6PD could be purified from human erythrocyte, however, when purified from plant tissue, it was observed to be unstable [68]. This unstable nature of G6PD in general has been the major setback in its purification from various sources, which consequently hinders its successful elucidation and as a result many research work involve the use of crude extracts or partially purified samples. Table 2 shows some of the sources G6PD have been well purified, while Table 3 shows some biochemical properties of the enzyme.

\section{Structural Characteristics of G6PD}

The structure of G6PD can be described in three categories, which includes primary, secondary and tertiary structure.

\subsection{Primary Structure of G6PD}

It involves the arrangement of the amino acids linked by peptide bonds in a linear sequence [78]. Though G6PD is found in many organisms, the primary structures as well as their amino acids composition slightly varies between organisms due to the enzyme's heterogeneous nature as shown in Table 4 and 5.
$64.2 \%$ of the amino acid residues of G6PD are highly conserved in most organisms with the homo-dimer of the enzyme having a unique structure due to each amino acid residue occurring twice in symmetrical positions [14]. As example, the complete amino acid sequence of human erythrocytes G6PD is made up of 531 amino acid residues $[79,80]$ containing a reactive lysyl residue that further explains its catalytic function with $\mathrm{C}$-terminal and $\mathrm{N}$-terminal sequence [81], even though it was previously assumed that the N-terminus of the human G6PD is blocked [82]. The Nterminal was identified to be pyroglutamic acid, while that from Saccharomyces cerevisiae was tyrosine [83, 84]. The $\mathrm{N}$-terminals from the two subunits of $C$. utilus are glycine and alanine [3]. The C-terminals of the two C. utilus subunits are the same though; they consist of glycine [80]. Just like human G6PD, the G6PD of L. mesenteroides also contains a region which controls catalytic activity in the primary sequence. This suggests that the G6PD in both organisms are structurally related despite functional and structural differences $[3,81]$.

\subsection{Secondary Structure of G6PD}

The secondary structure of G6PD involves the arrangement of the $\alpha$-helical and the $\beta$-pleated sheet structure expressed in various organisms. G6PD monomer is made up of two domains which are connected by $\alpha$-helix $[16,95-97]$. The larger domain has a $\beta-\alpha$ fold predominantly with nine antiparallel $\beta$-sheet strands, while the smaller domain has a typical $\beta-\alpha-\beta$ dinucleotide binding fold [80]. According to Rowland et al. [80], conservation in the $\beta-\alpha-\beta$ domain is minimal with only 17 of the 177 residues totally conserved. Recent studies have shown that $L$. mesenteroides G6PD has a higher level of the $\alpha$-helical structure than the $\beta$-pleated 


\section{International Journal of Science and Research (IJSR) \\ ISSN (Online): 2319-7064}

Index Copernicus Value (2013): 6.14 | Impact Factor (2013): 4.438

structure as determined at $2.0 \AA$ resolution as shown in Figure G6PD from $S$. cerevisiae showed a low level of $\alpha$-helical $2[16,80]$. However, studies on the secondary structure of structure [3].

Table 2: Organisms where G6PD have been successfully purified

\begin{tabular}{|l|l|l|}
\hline SOURCE & PURIFICATION PROCESS & REFERENCE \\
\hline Neurospora crassa & $\begin{array}{l}\text { Ammonium sulphate precipitation, calcium phosphate gel adsorption, } \\
\text { DEAE-Cellulose, hydroxyl apatite and bio-gel A column } \\
\text { chromatography }\end{array}$ & {$[35]$} \\
\hline Human erythrocyte & $\begin{array}{l}\text { DEAE Cellulose fractionation, Ammonium sulphate fractionation, } \\
\text { Affinity and anion exchange chromatography }\end{array}$ & {$[9]$} \\
\hline $\begin{array}{l}\text { Potato tuber (higher } \\
\text { plants })\end{array}$ & Ammonium sulphate fractionation and affinity chromatography & {$[68]$} \\
\hline $\begin{array}{l}\text { Chlamydomonas } \\
\text { reinhardtii }\end{array}$ & $\begin{array}{l}\text { SDS-PAGE, Ammonium sulphate fractionation, immunoblotting, } \\
\text { Bradford method }\end{array}$ & {$[28]$} \\
\hline $\begin{array}{l}\text { Lamb } \\
\text { cortex }\end{array}$ & $\begin{array}{l}2^{\prime \prime}, 5^{*} \text {-ADP-Sepharose 4B affinity gel chromatography and DEAE } \\
\text { Sepharose fast flow }\end{array}$ & {$[69]$} \\
\hline $\begin{array}{l}\text { Rainbow trout } \\
\text { ammonium sulphate precipitation and 2",5"-ADP-Sepharose 4B } \\
\text { affinity gel chromatography }\end{array}$ & $\begin{array}{l}\text { Ammonium sulphate fractionation, Reactive Blue 2 Agarose affinity } \\
\text { and Sephacryl S-200 Gel filtration chromatography }\end{array}$ & {$[30]$} \\
\hline $\begin{array}{l}\text { Aspergillus } \\
\text { aculeatus }\end{array}$ & & \\
\hline
\end{tabular}

Table 3: Some biochemical properties of G6PD isolated from various organisms

\begin{tabular}{|c|c|c|c|c|c|c|c|}
\hline $\begin{array}{l}\text { Organisms / } \\
\text { Extraction } \\
\text { Buffer }\end{array}$ & Examples & $\begin{array}{l}\mathrm{K}_{\mathrm{m}} \text { for } \\
\text { NADPH } \\
(\mu \mathrm{M})\end{array}$ & $\begin{array}{l}K_{\mathrm{m}} \text { for } \\
\text { G6P } \\
(\mu \mathrm{M})\end{array}$ & $\begin{array}{l}\mathrm{V}_{\max } \\
\text { (U/mg) }\end{array}$ & $\begin{array}{l}\text { Optimum } \\
\text { pH }\end{array}$ & $\begin{array}{l}\text { Optimum } \\
\text { temperature }\left({ }^{\circ} \mathrm{C}\right)\end{array}$ & References \\
\hline $\begin{array}{l}\text { Bacteria/ } \\
\text { Tris. } \mathrm{HCl}\end{array}$ & $\begin{array}{l}\text { Thiobacillus ferooxidans } \\
\text { Acetobacter hansenii } \\
\text { Leuconostoc mesenteroides } \\
\text { Acetobacter hensenni } \\
\text { Azotobacter vinelandii } \\
\text { Thermotoga maritima }\end{array}$ & $\begin{array}{l}24.3 \\
340 \\
5.69 \\
340 \\
50 \\
50\end{array}$ & $\begin{array}{l}53.9 \\
89 \\
81 \\
89 \\
30\end{array}$ & 20 & $\begin{array}{l}7.8-7.9 \\
7.0-8.5 \\
8.5\end{array}$ & $\begin{array}{l}50 \\
92\end{array}$ & $\begin{array}{l}{[70]} \\
{[71]} \\
{[72]} \\
{[70]} \\
{[73]} \\
{[74]}\end{array}$ \\
\hline $\begin{array}{l}\text { Algae/ } \\
\text { Tris. } \mathrm{HCl}\end{array}$ & Chlamydomonas reinhar ditii & & & & $7.0-9.5$ & 25 & {$[28]$} \\
\hline $\begin{array}{l}\text { Fungi/ } \\
\text { Tris. } \mathrm{HCl}\end{array}$ & $\begin{array}{l}\text { Neurospora crassa } \\
\text { Aspergillus aculeatus }\end{array}$ & $\begin{array}{l}12 \\
6\end{array}$ & $\begin{array}{l}37 \\
75 \\
\end{array}$ & & $\begin{array}{l}7.4-8.2 \\
7.5\end{array}$ & 55 & $\begin{array}{l}{[35]} \\
{[30]}\end{array}$ \\
\hline Higher plants & $\begin{array}{l}\text { Pealeaves } \\
\text { Potato tubers } \\
\text { Spinach }\end{array}$ & $\begin{array}{l}500 \\
6\end{array}$ & $\begin{array}{l}2000 \\
260 \\
400 \\
\end{array}$ & & $\begin{array}{l}8.0 \\
7.5-9.0 \\
9.0-9.5 \\
\end{array}$ & & $\begin{array}{l}{[68]} \\
{[39]} \\
{[75]}\end{array}$ \\
\hline $\begin{array}{l}\text { Mammals/' } \\
\text { Glycine/NaOH }\end{array}$ & $\begin{array}{l}\text { Dog erythrocyte } \\
\text { Lamb kidney cortex } \\
\text { Buffalo erythrocyte } \\
\text { Rat small intestine }\end{array}$ & $\begin{array}{l}18 \\
4.8\end{array}$ & $\begin{array}{l}36 \\
41\end{array}$ & 28.23 & $\begin{array}{l}8.0 \\
8.1\end{array}$ & 38 & $\begin{array}{l}{[7]} \\
{[69]} \\
{[56]} \\
{[75]}\end{array}$ \\
\hline $\begin{array}{l}\text { Birds/ } \\
\text { Tris.HCl }\end{array}$ & $\begin{array}{l}\text { Goose erythrocyte } \\
\text { Turkey erythrocyte }\end{array}$ & $\begin{array}{l}7.4 \\
17.1\end{array}$ & $\begin{array}{l}24.3 \\
49.7\end{array}$ & & 7.0 & $\begin{array}{l}50 \\
50\end{array}$ & $\begin{array}{l}{[13]} \\
{[77]}\end{array}$ \\
\hline Fish/Tris. $\mathrm{HCl}$ & Rainbow trout erythrocyte & 166 & 500 & 1.352 & 8.9 & 45 & [17] \\
\hline
\end{tabular}

Table 4: Variations of amino acid residues among organisms

\begin{tabular}{|c|c|c|}
\hline Organisms & Amino acid residues & References \\
\hline Leuconostoc mesenteroides & 488 & {$[85]$} \\
\hline E. coli & 490 & {$[86]$} \\
\hline Plasmodium falciparum & 994 & {$[48]$} \\
\hline Saccharomyces cerevisiae & 504 & {$[87]$} \\
\hline Rattus sp. (rat) & 513 & {$[88]$} \\
\hline Rodentia sp.(mouse) & 514 & {$[89]$} \\
\hline Human Erythrocytes & 531 & {$[3,80]$} \\
\hline
\end{tabular}

Volume 5 Issue 4, April 2016

www.ijsr.net 


\section{International Journal of Science and Research (IJSR) \\ ISSN (Online): 2319-7064}

Index Copernicus Value (2013): 6.14 | Impact Factor (2013): 4.438

Table 5: Amino acid composition of G6PD in various organisms

\begin{tabular}{|c|c|c|c|c|c|c|c|c|c|c|c|c|c|c|c|c|c|c|c|}
\hline \multirow{2}{*}{ ORGANISMS } & \multicolumn{18}{|c|}{ AMINO ACIDS } & \multirow[t]{2}{*}{ REFERENCES } \\
\hline & Asx & Thr & Ser & $\mathrm{Glx}$ & Pro & Gly & $\mathrm{Ala}$ & Cys & Val & Met & Ile & Leu & Tyr & Phe & Lys & His & Arg & $\operatorname{Trp}$ & \\
\hline L. mesenteroides & 144 & 48 & 44 & 104 & 30 & 70 & 116 & 0 & 60 & 18 & 52 & 72 & 44 & 64 & 74 & 12 & 36 & 16 & [3] \\
\hline B. subtilis & 130 & 52 & 54 & 108 & 54 & 60 & 76 & 4 & 58 & 20 & 68 & 86 & 50 & 40 & 62 & 26 & 44 & 10 & [3] \\
\hline C. utilis $(A s-75)$ & 134 & 44 & 67 & 106 & 49 & 83 & 67 & 14 & 57 & 15 & 47 & 81 & 32 & 42 & 89 & 12 & 35 & 10 & [90] \\
\hline C. utilis $(A s-95)$ & 103 & 47 & 64 & 110 & 42 & 72 & 70 & 8 & 51 & 14 & 47 & 78 & 34 & 42 & 88 & 23 & 42 & 10 & [90] \\
\hline C. utilis (Sigma) & 118 & 50 & 64 & 130 & 29 & 85 & 51 & 10 & 85 & 8 & 42 & 82 & 40 & 48 & 76 & 18 & 41 & 9 & [91] \\
\hline S. cerevisiae & 96 & 30 & 44 & 80 & 35 & 50 & 59 & 4 & 50 & 12 & 36 & 60 & 28 & 39 & 54 & 14 & 36 & 8 & [92] \\
\hline N. crassa & 101 & 43 & 59 & 100 & 45 & 60 & 52 & 32 & 51 & 34 & 56 & 76 & 39 & 40 & 71 & 21 & 57 & 14 & [35] \\
\hline $\begin{array}{c}\text { Human } \\
\text { eryythrocyte } \\
\text { (variant B) }\end{array}$ & 99 & 41 & 50 & 114 & 63 & 72 & 58 & 18 & 55 & 23 & 41 & 84 & 35 & 46 & 51 & 24 & 47 & 13 & [3] \\
\hline $\begin{array}{l}\text { Bovine adrenal } \\
\text { cortex }\end{array}$ & 111 & 59 & 74 & 134 & 48 & 96 & 75 & 16 & 85 & 24 & 59 & 83 & 45 & 49 & 55 & 29 & 65 & 19 & [93] \\
\hline Mouse liver & 122 & 62 & 60 & 138 & 52 & 96 & 80 & 12 & 84 & 28 & 60 & 104 & 42 & 56 & 78 & 24 & 68 & ND & [94] \\
\hline
\end{tabular}

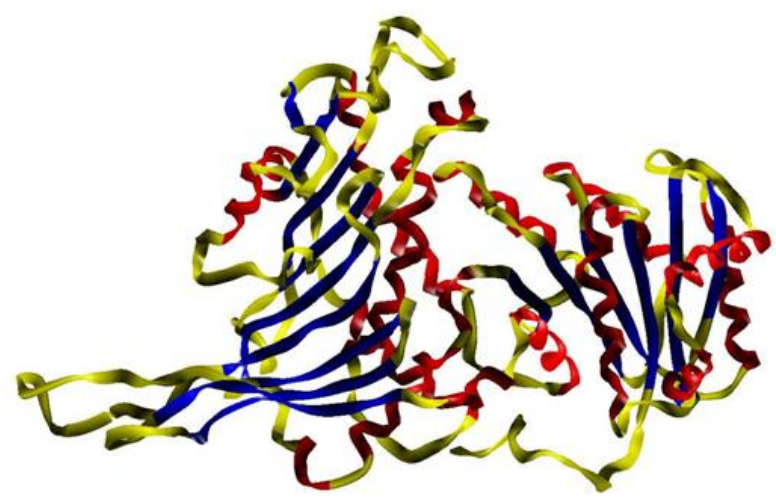

Figure 2: Three dimensional secondary structure of $L$. mesenteroides G6PD showing $\alpha$-helix (in red) and $\beta$-sheet (in blue). Adapted from Rowland [80]

Kotaka et al. [98] elucidated the secondary structure of the human G6PD dimer. It was found to contain $\beta-\alpha$ binding domain with a high degree of $\alpha$-helical structure (Figure 3 ). Similarly, mouse liver G6PD also showed a high degree of $\alpha$ helical structure [94]. However isozymes of C. utilis As-75 and As-95 G6PDs were discovered to have low $\alpha$-helical structure [99]. Thus according to Kotaka et al. [98], the human G6PD is similar to the L. mesenteroides G6PD; a dimer having a $\beta+\alpha$ domain interface.

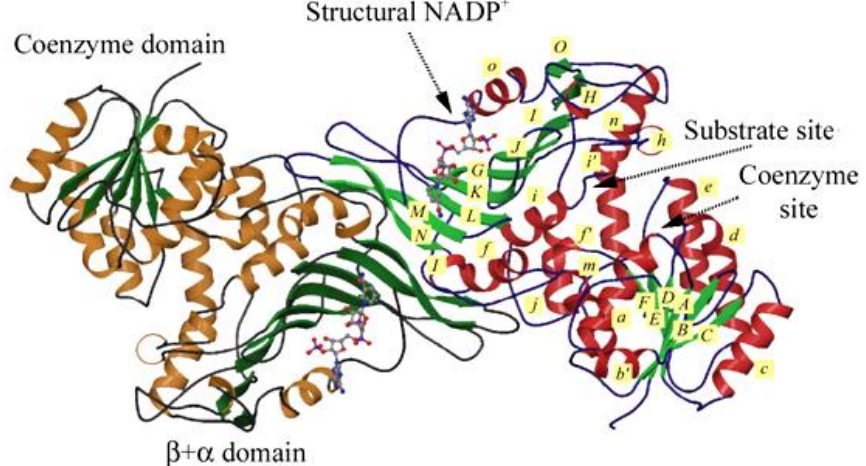

Figure 3: Human G6PD dimer enzyme, showing $\alpha$-helix (in red) and $\beta$-sheet (in green). Adapted from Kotaka et al. [98]

\subsection{Tertiary Structure of G6PD}

Most isolated G6PD has a single dimeric structure as the minimum structural requirement for catalytic activity, although some occurs also as monomer, trimer, tetramer or as hexamer [3, 35]. Some of the various forms of G6PD as revealed in several organisms are illustrated in Table 6.

Table 6: Various forms Catalytically Active G6PD

\begin{tabular}{|c|c|c|}
\hline Organisms & Nature & References \\
\hline Human electrolyte; A aculeatus; L. mesenteroides & Dimes & {$[30,80,100]$} \\
\hline A nidulans and $A$ niger & Trimes & [101] \\
\hline N. crassa & $\begin{array}{l}\text { Occurs mostly as tetramer, may } \\
\text { also occur as dimer }\end{array}$ & {$[35]$} \\
\hline 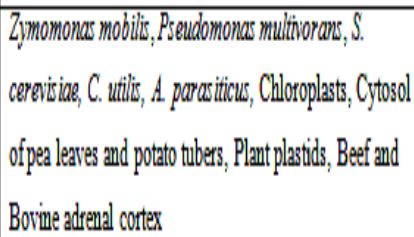 & Tetramer & $\begin{array}{l}{[7,39,56,68} \\
75,76]\end{array}$ \\
\hline
\end{tabular}

\subsection{Structure of the Active Site}

With the catalytic form been a dimer, G6PD portrays different configuration of their active site between human and microbes [80]. As observed in L. mesenteroides, the dimer interface is close to the active site, located at the edge and more stable than monomeric form when in aqueous solutions [21]. It also reveals one $\mathrm{NADP}^{+}$molecule is present in every subunit of tetramer, away from the active site but close to dimer interface [102].

On the other hand, G6PD in humans contains two NADP ${ }^{+}$ binding site in each subunit. The first is the catalytic site and the second is the structural site. However, $\mathrm{NADP}^{+}$which is required to aid folding and monomer hybridization is bound at the structural site and not involved in the catalysis of the enzyme [16, 103, 104]. The auxiliary cofactor helps to maintain the stability and integrity of the enzyme when it is in its active form [105]. Generally, the structural site of NADP ${ }^{+}$ is found and conserved in higher organisms [98].

\subsection{Coenzyme Binding Site}

The coenzyme associated with G6PD in most organisms is NADPH, although some organisms like L. mesenteroides could exhibit either NADH or NADPH [106]. In addition, 


\section{International Journal of Science and Research (IJSR) \\ ISSN (Online): 2319-7064 \\ Index Copernicus Value (2013): 6.14 | Impact Factor (2013): 4.438}

the coenzyme binding domain in L. mesenteroides contains 177 residues which consist of dinucleotides folds that can be aligned with the folds in other dehydrogenases present in the PPP [80]. Two major differences in the dinucleotide binding fold in dimeric G6PD which are likely to affect the niceties of coenzyme binding are found in the $\beta \mathrm{A}-\alpha \mathrm{a}$ loop and at the initial of $\alpha \mathrm{a}$ loop [71]. The first difference is the insertion of Gly-13 in the fingerprint and the second is the main chain conformation when proline (Pro-24) is present at the start of the helix aa loop [102]. Proline tends to distort the helix which causes the residue's 19-21 side chains to stretch towards the cleft at the boundary of the coenzyme bounding site making it possible for the coenzyme to bind by creating opportunity for conserved arginine to interact with the adenine ring and 2 phosphate of NADP [80]. On the other hand, a monomeric G6PD contains a coenzyme-binding domain at the amino terminus and a $\beta+\alpha$ domain at the carboxyl terminus, a second domain usually exist which indicates a new fold [102].

Sequenced G6PD has also shown that Gly-12, Gly-15, Arg16 and Leu-17 are conserved at the coenzyme binding site. Further work also shows that glycine might be also conserved at region 219, although its use has been deemed irrelevant [80].

\subsection{Substrate Binding Site}

The substrate most associated with G6PD is glucose 6phosphate (G6P). G6P is dehydrogenated at $\mathrm{C}-1$ to give 6phosphogluconolactone (Figure 1). In L. mesenteroides, the substrate binding site has been assumed to be in the pocket which is located at the domain boundary with nine highly conserved peptide $[25,80,102]$.

G6P tend to bind in the position where its phosphate can make contact with each monomer, close to the conserved residues [78], as a result five residues which form ligands with the phosphate exist and are fully conserved in all species [80]. Lys-182 (in L. mesenteroides), which interacts with the second phosphate in subunit $\mathrm{A}$, is similar to the lysine in the human G6PD and important for catalytic activity. The side chain of Lys-148 is less tightly bound in subunit A than in subunit $\mathrm{B}$ as a result of the different conformations of the two proline residues (A149 and B149) in the two subunits. This leads to a tighter binding of phosphate in subunit B since only one phosphate binds in subunit B; although limited knowledge is provided on this [104, 105]. A theoretical reason might be that the specificity of the site of phosphate is greater if Pro-149 exist in a Trans in subunit B (Figure 3).

Also at the entrance of the active site cleft, a band of basic residues (Lys-19, Arg-20, Lys-21 and Lys-32) draw protons from the hydroxyl group of G6P in the absence of a metal ion and help the substrate bind in correct orientation [80].

\subsection{Substrate Specificity}

Naturally, G6P is the substrate for all G6PD enzymes, having the highest $V_{\max }$ in all G6PD enzymes [3, 107]. However, recently phosphorylated monosaccharides like galactose 6phosphate and 2-deoxyglucose 6-phosphate were identified to be oxidizable by G6PD [16]. Research for further clarifications, revealed that substrates without ${ }^{-} \mathrm{OH}$ on $\mathrm{C}-2$ were oxidised by G6PD, an example is 2-deoxyglucose-6phosphate [107]. Even substrates with alteration such as replacement of $\mathrm{OH}$ with $-\mathrm{NH}_{2},-\mathrm{F}$ or $-\mathrm{Cl}$ at $\mathrm{C}-2$ were found to be tolerated by some forms of G6PD [16]. However, substrates that possessed bulky groups such as $-\mathrm{OCH}_{3}$ at $\mathrm{C}-2$ were not oxidized. Some substrate like galactose 6-phosphate that showed alteration at C-4 were weakly oxidized by G6PD, it thus implies that changes at C-4 is not as determining factor as changes in $\mathrm{C}-2[3,16]$.

Non-phosphorylated sugars, like isoesteric phosphonate, sulphate and glucose have also shown little compatibility with G6PDs [73], though some changes in substrate structure can be tolerated, activity and binding of G6PD are reduced, showing that G6PD has a high level of substrate specificity for G6P [30]. Apart from the substrate specificity, G6PD from various sources have displayed non-consistent affinity for coenzymes (Table 7), making it possible to classify them based on nucleotide specificity.

Table 7: Classes of G6PD based on nucleotide specificity

\begin{tabular}{|l|l|l|}
\hline \multirow{4}{*}{$\begin{array}{l}\text { G6PD from these organisms react } \\
\text { only with NADP }\end{array}$} & EXAMPLES & REFERENCES \\
\cline { 2 - 3 } & E. coli & {$[20]$} \\
\cline { 2 - 3 } & Brewers' yeast & {$[65]$} \\
\cline { 2 - 3 } & N. crassa & {$[35]$} \\
\cline { 2 - 3 } & Spinach leaves & {$[39]$} \\
\cline { 2 - 3 } & Aspergillus aculeatus & {$[30]$} \\
\cline { 2 - 3 } & Goose erythrocytes & {$[13]$} \\
\hline $\begin{array}{l}\text { G6PD from these organisms react } \\
\text { with NADP } \\
\text { activity with } \text { NAD }^{+}\end{array}$ & A.vinelandii & {$[108]$} \\
\hline \multirow{2}{*}{$\begin{array}{l}\text { G6PD from these organisms react } \\
\text { with both NADP }\end{array}$} & & \\
\cline { 2 - 3 } and NAD & & A.suboxydas \\
\cline { 2 - 3 } & L. mesenteroides & {$[108]$} \\
\cline { 2 - 3 } & Pseudomonas W6 & {$[11,109]$} \\
\hline
\end{tabular}

\subsection{Regulatory Properties of G6PD}

G6PD is regulated at transcriptional, translational, posttranslational levels and also at intracellular levels by various factors such as nutrition, hormone and oxidative stress [16].

\subsubsection{Nutritional Factors}

Studies on liver cells showed that excess dietary carbohydrate induced G6PD whereas starvation repressed it. This was identified as normal since an enzyme is only activated when its specific substrate is readily available [3]. Apart from carbohydrate availability, G6PD activity was also found to be regulated by the type of carbohydrate present in the diet, as work done on rats fed with diets high in glucose and starch had increased levels of G6PD activity [99], whereas high fat and low carbohydrate diets inhibit G6PD activity [111]. More nutritional regulatory is polyunsaturated fatty acids (PUFAs) which inhibit G6PD gene expression through a posttranscriptional mechanism whereby the splicing efficiency of pre-mRNA is decreased [112]. Insulin activation of phosphatidyl inositol 3-kinase pathway also tend to increases G6PD expression, while essential polyunsaturated fatty acids like arachidonic acid stops the accumulation of G6PD by inhibiting insulin signalling [16]. 


\section{International Journal of Science and Research (IJSR) \\ ISSN (Online): 2319-7064 \\ Index Copernicus Value (2013): 6.14 | Impact Factor (2013): 4.438}

\subsubsection{Hormonal Factors}

Insulin and dexamethasone have been revealed as an important hormone in upregulating G6PD expression at transcription level [16]. Glucocortoids have also been identified to activate G6PD in rat liver cells [113]. Epidermal growth factor similarly has an effect on G6PD by activating G6PD mRNA [114]. Norepinephrine particularly induces G6PD mRNA activity in the heart [116] and Vitamin D in the epithelium of the gut [116].

\subsubsection{Oxidative Stress}

Substances that produce oxygen radicals tend to activate G6PD by the use of SoxR regulon, thereby upregulating the enzyme and other genes required to protect cells from free radical damage [12]. An example was the exposure of type II pneumocytes to hyperoxia which resulted to a high level of G6PD activity in mammalian neonatal rats ${ }^{\text {ec }}$ lungs [16]. G6PD in the liver could also be induced by chemicals like diquat and ethanol [117].
In higher plants, G6PD is regulated by transcriptional and translational processes. In plants like alfalfa, the root nodules containing fungi have been observed to induce G6PD transcription and activity [118]. Light also tend to induces plastidic G6PD expression in light deprived potato shoots since plastidic G6PD can be activated by a low level of $\mathrm{NADPH}$ to $\mathrm{NADP}^{+}$ratio [119].

\subsection{Inhibition of G6PD}

NADPH is an effective inhibitor of NAD-linked G6PD and a competitive inhibitor of NADP-linked G6PD [18]. Studies involving $L$. mesenteroides showed that when G6P was the substrate of varied concentration, inhibition was linearly noncompetitive but when $\mathrm{NADP}^{+}$was the substrate of varied concentration, linear competitive inhibition was obtained [80]. Random inhibitors of G6PD include phosphoenolpyruvate, ATP, fructose 6 phosphate and $\mathrm{Co}^{2+}$ [30], although some inhibitors are peculiar to some organisms (Table 8).

Table 8: Possible G6PD inhibitors in some organisms

\begin{tabular}{|l|l|l|}
\hline ORGANISMS & G6PD INHIBITOR & REFERENCES \\
\hline Pseudomonas W6 & NADH & {$[120]$} \\
\hline $\begin{array}{l}\text { Methylomonans M15 } \\
\text { and S. aureofaciens }\end{array}$ & NADPH and NADH & {$[121]$} \\
\hline Human placenta & NADPH & {$[122]$} \\
\hline Anabaena spp & NADPH & {$[19]$} \\
\hline $\begin{array}{l}\text { Yeast, bacteria, fungi } \\
\text { and plants }\end{array}$ & NADH and NADPH & {$[30,55,70]$} \\
\hline Brewers' yeast & $\begin{array}{l}\text { D-glucosamine 6 phosphate, Pregnenolone and } \\
\text { dehydroisoandrosterone at concentrations } \leq 10^{-6}\end{array}$ & {$[123]$} \\
\hline Red blood cells & $\begin{array}{l}\text { Cyanate, some antibiotics, Aluminium, nickel } \\
\text { and cadmium }\end{array}$ & {$[56]$} \\
\hline
\end{tabular}

\subsection{Multiple Variants of G6PD}

Isozymes or variants of G6PD usually occur as a result of genetic mutations and results to wide ranging levels of enzyme activity (Table 3, 4 and 5) and associated clinical symptoms. According to Notaro et al. [14], 122 mutations of human G6PD have been identified and 114 of these mutations are as a result of missense mutations. Of these 114 mutations, 106 have single mutations, 7 have two mutations and 1 has three mutations. Six mutations contain in-frame deletions (four single amino acid deletions, one double amino acid deletions and one eight-amino acid; deletions). 1 of the variant is due to nonsense mutations and another due to a splicing site mutation. Of all human variants of G6PD, three have no effect on enzyme activity, while the others cause some form of the enzyme deficiency [14]. 57 mutations are associated with nonspherocytic haemolytic anaemia (WHO class I severe phenotype) and 58 mutations have a high risk of acute haemolytic anaemia (WHO classes II and III, mild phenotype) [14].

Notaro et al. [14], emphasised that most of the human mutations responsible for G6PD mutations are genetic and „null ${ }^{\text {le }}$ (includes early nonsense mutations; mutations in the coenzyme or substrate binding regions; mutations destroying the reading frame; and yet to be identified mutations). In human G6PD, mutations occur throughout the amino acid sequence and are completely conserved [61]. Partially conserved amino acids are usually not represented properly in G6PD-deficient mutants unlike fully and moderately conserved amino acids which are over-represented in these variants. Usually, $83 \%$ of all microorganisms ${ }^{\text {ee }}$ G6PD don ${ }^{\text {eq }}$ exhibit a replacement of amino acid sequence peculiar to human isozymes and therefore do not alter enzymatic activity. In some cases, the residues that are altered are found normal in other organisms. Comparing the distribution of mutations in a human gene is very useful in elucidating the function of domains and even individual amino acids in a protein $[14,16]$. To do this various range of potential, clinical consequences of the several mutations of G6PD are considered, some of them include:

- Mutations such as null mutation which is deleterious and can 'it support life [61]. An experiment performed by [14] on mice, proved that G6PD null mutations didn't support the survival past the embryonic stage of development.

- Mutations which causes G6PD protein molecules to lack stability. This tends to make G6PD deficient in erythrocytes, affecting the normal activity of red blood cells.

\section{Volume 5 Issue 4, April 2016}




\section{International Journal of Science and Research (IJSR) \\ ISSN (Online): 2319-7064 \\ Index Copernicus Value (2013): 6.14 | Impact Factor (2013): 4.438}

- Mutations that affect coenzyme and substrate binding. This affects the catalytic mechanism and hence the cell that contains them tends to cluster. However, these clusters are yet to be identified. The only cluster of mutations occur between amino acid residue 380 and 410 and this is similar to the subunit interface in the G6PD dimer which is enzymatically active $[87,96,124]$.

The unique pattern of mutation of G6PD therefore reveals that more than two thirds of the amino acid alteration that cause G6PD deficiency are present in highly and moderately conserved amino acids with a few in poorly conserved amino acids [96]. This shows that the more the number of conserved amino acids that are mutated the more the effect; therefore mutation of fully conserved amino acid will tend to be deleterious while mutation of moderately conserved amino acids may cause instability but not lethal, whereas mutation of poorly conserved amino acids may go undetected.

G6PD is the only housekeeping enzyme in which most of the identified mutations are both pathogenic and polymorphic

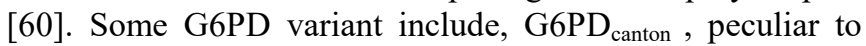
South China, which was observed to be as an alteration in nucleotide position 1376 of the cDNA (from G to T) which results in a genomic mutation in amino acid position 459, from arginine to leucine [95]. Other G6PD variants cause nonspherocytic anaemia, which is as a result of deletion or alteration around exon 10 necessary for substrate binding. It has been shown in some situations that G6PD mutation may cause the individual to be less susceptible to malaria [125].

\section{Biological Importance of G6PD}

The major role of the pentose pathway is for the production of NADPH, which provides reducing power to aid various reductive biosynthetic processes and serve as electron donor for many enzymatic reactions. In mammals, NADPH from the PPP is used in tissues like the liver for fatty acid synthesis and cholesterol metabolism, in the testes for steroid synthesis, adipose tissues for fatty acid synthesis, ovaries for steroid synthesis, mammary glands for fatty acid synthesis (during lactation and development of embryo) adrenal gland for steroid synthesis and red blood cells for the maintenance of reduced glutathione which is used to fight against oxidative stress $[25,99]$. G6PD is also useful for cell survival as it is involved in the production of ribose-5-phosphate which is a precursor for nucleic acid synthesis [10].
As G6PD variant exist amongst organisms, they possess various role in their cellular environment as described in Table 9 .

Generally, the antioxidant system depends on NADPH production to function well. For instance, the generation of $\mathrm{GSH}$ by glutathione reductase is dependent on NADPH production. Catalase also needs NADPH for its maintenance in its active conformation in the allosteric binding site [12]. Although, superoxide dismutase doesn't use NADPH to convert superoxide to hydrogen peroxide, but superoxide needs to be reduced by catalase or glutathione which are dependent on NADPH. The nitric oxide synthase (NOS) needs NADPH to be able to convert arginine to citrulline and nitric oxide [12].

Also, NADPH oxidases are dependent on NADPH from G6PD which are involved in cell growth and white blood cell function. They are also involved in pathological situations like diabetes and cardiovascular diseases, which are a major source of reactive oxygen species [130]. Many other systems dependent on NADPH include lipid production such as 3hydroxy-3-methylbutaryl-CoA reductase and NADPH cytochrome $\mathrm{P} 450$ oxidoreductases which is required for drug metabolism and steroid metabolism [131].

\subsection{The Deficiency of G6PD}

G6PD deficiency is the most common enzyme deficiency; affecting more than 400 million people worldwide (Figure 4) with more cases in malaria prone zones [8]. G6PD deficiency was first identified in 1956, with most cases in Africa, Middle East, Mediterranean regions and Indochina; with few cases in some part of northern Europe, North and South America [8, 132].

G6PD deficiency was initially identified in black Americans as primaquine's sensitivity to anaemia peculiar to the Carribeans and the Mediterranean region when patients were treated with 6-methoxy-8-aminoquinolinne drugs against malaria and haemolytic anaemia was diagnosed [132]. To determine why some antimalarials caused acute haemolysis, an experiment using ${ }^{51} \mathrm{Cr}$ technique was carried out using volunteer prisoners at Illinois State Penitentiary in Chicago. It revealed that that the sensitivity to primaquine was because of dome internal defect of the red blood cells attributed to G6PD deficiency, eventually causing haemolytic anaemia [8, 133]. 


\section{International Journal of Science and Research (IJSR) \\ ISSN (Online): 2319-7064}

Index Copernicus Value (2013): 6.14 | Impact Factor (2013): 4.438

Table 9: Specific role of G6PD in some organisms

\begin{tabular}{|c|c|c|}
\hline ORGANISMS & RELEVANCE OF G6PD & REFERENCE \\
\hline $\begin{array}{l}\text { Fungi like } N \text {. } \\
\text { crassa and } A \text {. } \\
\text { flavus }\end{array}$ & $\begin{array}{l}\text { Provide NADPH by PPP for fatty acid biosynthesis for growth and } \\
\text { development. }\end{array}$ & [35] \\
\hline Bacteria & $\begin{array}{l}\text { Reduce oxidative stress and assist in the production of } \\
\text { ribonucleotides used as precursors for DNA synthesis. Some } \\
\text { bacteria like } L \text {. mesenteroides use the activity G6PD to create } \\
\text { products of fermentation }\end{array}$ & [109] \\
\hline Higher Plants & $\begin{array}{l}\text { Provides NADPH for steroid biosynthesis in the absence of light, } \\
\text { as the photosystem I\&II are readily unavailable when ultraviolent } \\
\text { light is limited. }\end{array}$ & [126] \\
\hline $\begin{array}{l}\text { Mammary } \\
\text { glands }\end{array}$ & $\begin{array}{l}\text { Provides NADPH for milk fat biosynthesis by PPP which is } \\
\text { suspended after weaning }\end{array}$ & [127] \\
\hline $\begin{array}{l}\text { Mammalian } \\
\text { embryo }\end{array}$ & Helps to supply the embryo with maternal blood glucose & [128] \\
\hline Fish & $\begin{array}{l}\text { G6PD activity is necessary during the period of blood system } \\
\text { development, hatching and completion of resorption. }\end{array}$ & [129] \\
\hline Human & $\begin{array}{l}\text { Apart from several functions, G6PD is highly important in } \\
\text { erythrocyte since they have no alternative source of NADPH as } \\
\text { they lack mitochondria. The NADPH supplied help to form } \\
\text { reduced GSH in order to curb free radicals, as red blood cells tend } \\
\text { to liberate several free radicals due to their conversion of } \\
\text { oxyhaemoglobin to deoxyhaemoglobin and other cellular activities. } \\
\text { Therefore, NADPH prevents haemoglobin denaturation, preserves } \\
\text { the integrity of erythrocyte cell membrane sulfhydyl groups and } \\
\text { detoxifies oxygen radicals and hydrogen peroxide in and on the } \\
\text { erythrocytes. If G6PD is limited the haemoglobin sulfhydyl groups } \\
\text { will no longer be maintained in its reduced form, making } \\
\text { molecules of haemoglobin to cross link with one another forming } \\
\text { aggregates called Heinz bodies on the cell membranes which } \\
\text { accumulate and cause lysis }\end{array}$ & [17] \\
\hline
\end{tabular}

G6PD deficiency is an X-linked hereditary defect prevalent in males that occurs as a result of G6PD gene mutations. This leads to variant forms of the gene with various biochemical and clinical manifestations with a $10 \%$ reduction in general enzymatic activity [125]. G6PD deficiency creates the formation of different proteins with varying levels of enzyme activity [8], with clinical manifestations such as neonatal

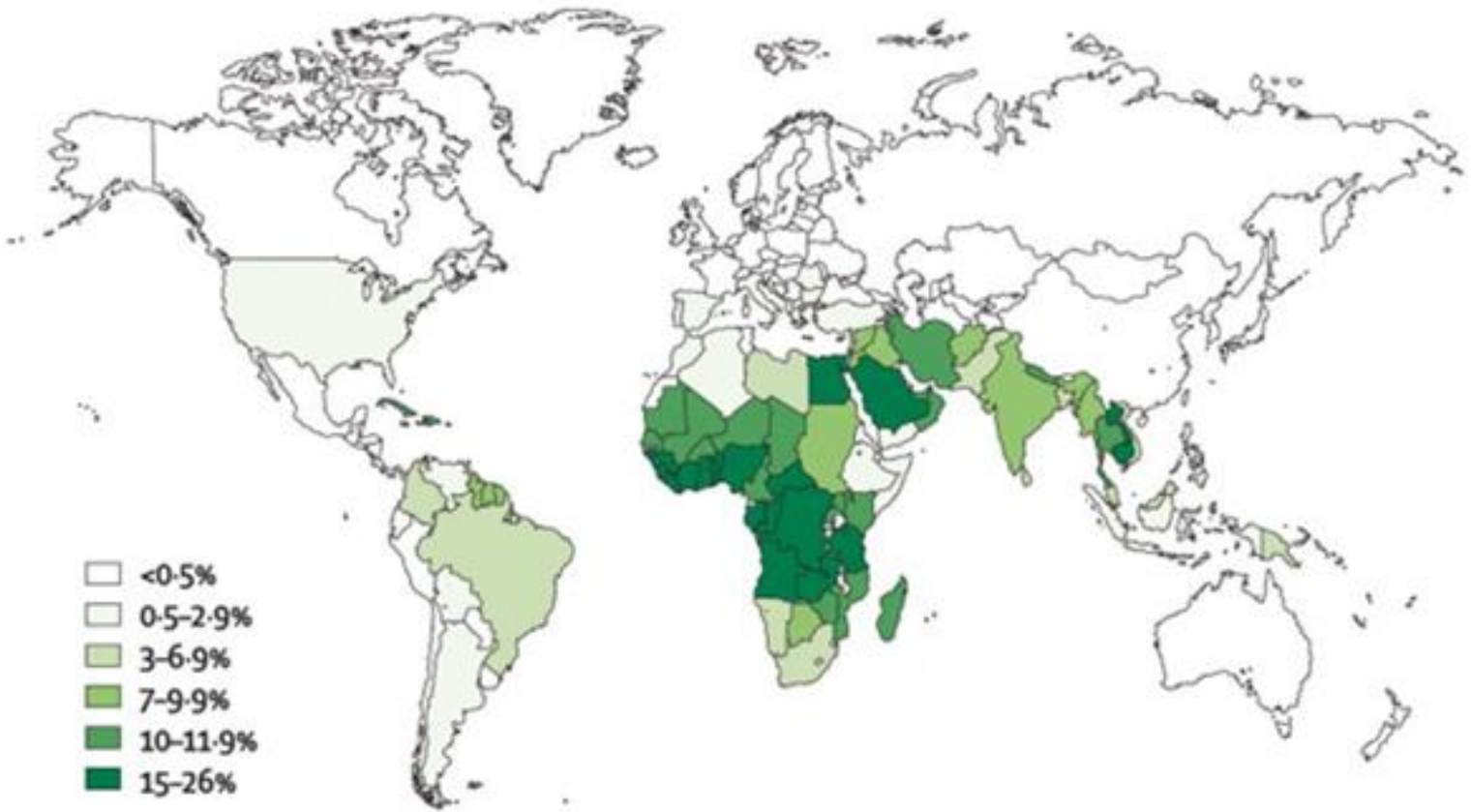

Figure 4: Map showing world distribution of G6PD deficiency. Adapted from Cappellini and Fiorelli [8]. 


\section{International Journal of Science and Research (IJSR) \\ ISSN (Online): 2319-7064 \\ Index Copernicus Value (2013): 6.14 | Impact Factor (2013): 4.438}

jaundice (NNJ), acute haemolytic anaemia, chronic haemolysis which leads to chronic nonspherocytic haemolytic anaemia (CNSHA) [104]. These clinical manifestations are usually triggered by external factors such as drugs and fava beans [133].

\subsection{Classes of G6PD Deficiency}

The physical manifestations of G6PD are heterogenous with more than 140 gene mutations identified [8]. In 1962, WHO characterised G6PD deficiency into five classes based on enzyme activity, electrophoretic mobility of the enzyme, kinetic parameters $\left(\mathrm{K}_{\mathrm{m}}\right.$ for NADP and G6P, substrate analogues and dependence of $\mathrm{pH}$ ), physicochemical properties and clinical manifestations [8]. G6PD could also be classified as polymorphic or sporadic [14]. These classes include:

- Class I: Highly deficient with chronic non-spherocytic haemolytic anaemia;

- Class II: Highly deficient (1-10\% residual activity). It is associated with acute haemolytic anaemia;

- Class III: Moderately deficient (10-60\% residual activity). Haemolysis is self-limiting;

- Class IV: Normal activity (60-150\%); and,

- Class V: Increased activity (>150\%).

\subsection{Clinical Manifestations of G6PD Deficiency}

Although, most G6PD deficient individuals don et exhibit any symptoms of this defect nor a reduction in life span, the most common manifestation is haemolysis which occurs usually when erythrocytes undergo oxidative stress induced by drugs, fava beans or infection [133].

Some of the clinical manifestations of G6PD include neonatal jaundice, favism, drug-induced haemolytic anaemia, infection-induced haemolytic anaemia and chronic nonspherocytic haemolytic anaemia [104]. Sometimes, heart

attack and diabetes could also induce haemolysis in individuals who are G6PD deficient [14]. Associated with the clinical manifestations are tiredness, anaemia, back ache and jaundice. Other markers include lactate dehydrogenase and unconjugated bilirubin [104]

\subsubsection{Infection - Induced Haemolyitc Anaemia}

Infections such as hepatitis $\mathrm{A}$ and $\mathrm{C}$, typhoid fever and pneumonia could lead to anaemia in G6PD deficient individuals [8]. Severe haemolysis and kidney failure may affect viral patients who are G6PD deficient, leading to death. Studies have shown that drug metabolism might be distorted by hepatitis which could result in increased number of metabolites known to cause haemolysis [14]. Generally, hepatitis increases the total concentration of bilirubin and haemolysis [8].

\subsubsection{Favism}

Favism was first identified in the $20^{\text {th }}$ century, although the relationship between favism and G6PD deficiency was not established until much later. It was first discovered in the Mediterranean region [134]. It is specific to G6PD deficient individuals and involves an onset of haemolytic anaemia due to the ingestion of beans (like broad beans) or exposure to the bean pollens [8]. This could be attributed to the presence of divicine, isouracil, pamaquine and convicine in the beans that stimulates PPP activity and hence haemolysis [134]. Favism presents as haemolytic anaemia 24 hours after the beans were ingested. This is usually more serious than druginduced or infection-induced haemolytic anaemia and it could lead to kidney failure [134].

\subsubsection{Drug - Induced Haemolyitc Anaemia}

Certain drugs such as primaquine and sulphonamides induce haemolysis in G6PD deficient individuals (Table 10). This is owe to the fact that metabolism of drugs involves the production of reactive oxygen species, and with limited NADPH available to tackle the oxidants, haemolysis will thereby occur [112]. Some common symptoms of such cases may show brown to black urine (haemoglobinuria), jaundice, fever and anaemia. Although, the patient begins to recover over time since G6PD deficiency is a self-limiting process [8].

Table 10: Some drugs associated with G6PD deficiency. Adapted from Cappellini and Fiorelli [8]

\begin{tabular}{|c|c|c|c|}
\hline Drugs & Biological Action & Drugs & Biological Action \\
\hline Primaquine & \multirow{2}{*}{ Antimalarials } & Aspirin & \multirow{2}{*}{ Analgesics } \\
\hline Pamaquine & & Phenazopyridine & \\
\hline $\begin{array}{l}\text { Sulphonamides/ } \\
\text { Furazolidone }\end{array}$ & \multirow[b]{2}{*}{ Antimicrobials } & Doxorubicin & \multirow[b]{2}{*}{ Chemotherapy } \\
\hline $\begin{array}{l}\text { Quinolones/ } \\
\text { Dapsone/ } \\
\text { Niridazole }\end{array}$ & & Flutamide & \\
\hline
\end{tabular}

\subsubsection{Neonatal Jaundice}

Most male neonates, diagnosed with neonatal jaundice are usually G6PD deficient [8, 133]. Neonatal jaundice occurs later than normal physiological jaundice of $\mathrm{ABO}$ or $\mathrm{Rh}$ incompatibility. Kernicterus can occur and this could lead to sever neurological damage [133].

\subsubsection{Congenital Non - Spherocytic Haemolytic Anaemia (Cnsha)}

Chronic haemolysis caused by G6PD deficiency leads to CNSHA. The variants of G6PD that cause CNSHA are nonsporadic [8]. CNSHA is classified into two:

- Type I: When the raised level of haemolysis can be corrected by ATP; and,

- Type II: When the raised level of haemolysis cannot be corrected by ATP.

Most G6PD deficient people with CNSHA usually fall into the type I category. CNSHA usually occurs during childhood with elevated bilirubin and lactate dehydrogenase with occurrence of extra vascular haemolysis [133].

\subsubsection{Malaria Plasmodium Falciparum \& G6PD Deficiency}

Though G6PD deficiency has so many deleterious, ranging from anaemia to jaundice and even to death, it has an 


\section{International Journal of Science and Research (IJSR) \\ ISSN (Online): 2319-7064}

Index Copernicus Value (2013): 6.14 | Impact Factor (2013): 4.438

advantage under some certain conditions [133]. In G6PD deficient people, G6PD deficiency is used as a mechanism in the defence against Plasmodium falciparum since the plasmodium requires NADPH to produce reduced glutathione and ribonucleotides (for growth and development) in the host $[95,104]$.

\subsection{Prospects of G6PD in Biotechnology Applications}

The promising nature of biotechnology in the last two decades has lead to a great interest in possible ways to make it more effective in product development and production [135], thereby out phasing other cultural means of production [136]. Biotechnology stresses on the use of nature products with genetic modification in order to increase yield and quality of products [137].

One of the major biomaterials used in production are enzymes which tend to transform substrates to desired products [138]. However, some enzymes like G6PD show little implementation in biotechnology unless for laboratory studies $[138,140]$.

Although G6PD has been well researched in terms of the elucidation of its structure and properties; thus its biochemistry is very well understood. However, the prospects of this enzyme are yet to be well enact as literatures involving its applications are limited. Though it is know that G6PD is necessary for the synthesis of reductive potential (NADPH) and it is necessary for steroid and nucleotide biosynthesis and a host of other important functions such as its role in reducing oxidative stress; its applications industrially and in other areas are still being deciphered. Hence this section therefore provides proposed prospective uses and/or development of G6PD in biotechnology applications.

\subsubsection{In Fermentation}

Fermentation involves the use of microbes acting on solid or liquid substrate in anaerobic condition [140]. They are highly employed in production with the most popular been alcohol brewing and the commonest microorganism been Saccharomyces cerevisiae [141].

S. cerevisiae like any other organism thrive and multiply, thereby making use of the sugars in the fermenters releasing carbon dioxide and alcohol as by-products [140]. However, on accumulation, alcohol becomes lethal, giving the reason why most fermentation generally end with alcohol concentration of $10 \%-15 \%$, although some strains of Saccharomyces cerevisiae could survive up to $21 \%$ of alcohol [141]. Alcohol tends to eliminate the microbe by scavenging structural and functional molecules, causing oxidative stress $[142,143]$. Oxidative stress usually prevented by various molecules like glutathione, catalase, peroxidase and superoxide dismutase is dependent on the activity of G6PD (previously discussed section 3.0). Lojudice et al. [138] showed how G6PD could be over expressed in Saccharomyces cerevisiae by genetic modification. Therefore, the increase in the expression of G6PD in Saccharomyces cerevisiae during fermentation may tend to increase the quantity of alcohol production by increasing the survival rate of the organism.

\subsubsection{In Bioremediation}

The task of wastewater treatment still remains an issue in the safekeeping of the environment. Several methods have been employed in managing wastewater effluents in the society, however, with the most effective means been microbial remediation; several setbacks are however still encountered [144]. Among several impediments, a vital issue is the brief life span of microbes employed in the remediation process [144]. Major lethal pollutants that tamper the efficiency of these microbes are reactive oxygen species (ROS) that destroys the cellular structure of these microorganisms [145]. Although, ROS are essential in tertiary remediation with abilities to decolourize and eradicate pathogenic microbes, they tend to impede the initial activities of microbes necessary for wastewater treatment [146].

Studies performed by Lojudice et al. [138] proved that G6PD which plays a role in combating ROS can be over expressed in microbes. Hence, genetic amplification of G6PD in remediating microbes may have a tendency to increase their shelf life and therefore prolong their activity.

\subsubsection{In Enzyme Immobilization for Biofuel Production}

The use of immobilized enzymes has proven to be more effective and advantageous than free enzymes as these enzymes could be recycled and has greater thermal and operational stability.

Among several demands of fuel, the request of hydrogen gas is becoming highly recognised, and this has led to the development of several means of hydrogen gas production to match up with the demand [147]. Amongst several ways is the implementation of biotechnology in the production of hydrogen gas through fermentation process [140].

Research shown by Woodward et al. [148], proved that hydrogen gas been the main product from G6PD purified from Pyrococcus furiosus had a yield of $11.6 \mathrm{~mol} \mathrm{H}_{2}$ per mol glucose-6-phosphate. Also, studies done by Simons et al. [149] revealed that G6PD could be efficiently immobilized via genetically engineered cysteine, producing higher enzyme activity than the regular immobilized G6PD. Therefore, implementation of the improved technique of immobilized G6PD from Pyrococcus furiosus may tend to increase the yield and lower cost of constantly isolating G6PD.

\subsubsection{Cellulose Production}

Industrially, glucose 6 phosphate dehydrogenase is important in the production of bacterial cellulose in organisms like Acetobacter spp [150]. This bacterial cellulose is a gelatinous membrane that is produced at the surface of liquid culture by this organism. It could be eaten as "Nata de Coco" or used as a thickener, disperser, stabilizer, emulsifier, in paper, artificial skin, medical supplies and for cosmetics [150]. Thus, the higher activity of this enzyme in Acetabacter spp, the higher the yield of the bacteria cellulose. This therefore implies that increasing G6PD activity in this organism could boost its economic value.

\subsubsection{In Plant Defence Strategies}

The inhibition of G6PD in tobacco leaves has proved to be advantageous as it improves plant defence by preventing 


\section{International Journal of Science and Research (IJSR) \\ ISSN (Online): 2319-7064}

Index Copernicus Value (2013): 6.14 | Impact Factor (2013): 4.438

oxidative burst and formation of hypersensitive lesions induced by Phytophthora nicotianae infection, and was also shown to improve tolerance to drought [151]. Thus transgenic technologies may be applied to plants susceptible to infection by Phytophthora nicotianae and plants in the arid regions, making them more resistant and likely to survive harsh weather conditions like drought. Inhibition of G6PD activity could therefore be exploited as a means of biological control as insecticides, pesticides and herbicides.

\subsubsection{In Disease Diagnosis}

Due to the fact that G6PD is important for cell growth, G6PD activity could be used in the detection of diseases. Studies suggest that decreased G6PD activity may lead to the development of diabetes on the basis of correlations of increased frequency of diabetes mellitus in G6PD deficient subjects compared to individuals in the same population who have normal G6PD activity $[16,111]$. Decreased activity of G6PD was shown to adversely affect pancreatic cells, as these cells already have low level of antioxidant production. Thus the level of G6PD may be used as a marker in the diagnosis of some ailments.

Furthermore, the over expression G6PD was found to be required for prostate cancer cell proliferation [152] as its expression was increased upon androgen treatment in hormone sensitive prostate cancer cell lines. Thus it was suggested that G6PD activity could be used as a clinical marker for prostate cancer exams as its activity were found to be four times higher in carcinomas than in benign prostatic hyperplasia [152].

\section{Conclusion}

Although the biochemistry of the G6PD that catalyzed the most essential step in the pentose phosphate pathway, producing the reducing power in form of NADPH and which is essential for numerous biosynthetic pathways from the least microorganism to the highest in the plant and animal phyla is well understood; its huge potentials is still not been fully utilized for biotechnological applications. Thus we anticipate this review will be a gateway for more critical reasons and innovations into how G6PD enzyme could be judiciously used in solving or overcoming biotechnological applications challenges.

\section{Acknowledgement}

The Federal University Oye-Ekiti, Ekiti State, Nigeria, is well appreciated for academic support.

\section{References}

[1] B. Alberts, D. Bray, J. Lewis, M. Raff, K. Roberts, J.D. Watson, Molecular Biology of the Cell, 3rd Edn. New York: Garland Publishing, Inc. 1994.

[2] G. W. Lohr, H. D. Waller. G6PD. In: Methods in Enzymatic Analysis Vol1: 6 73-681.Edited by H.U. Bergmeyer Weinheim: Verlag Chemie GMBH. 1974

[3] H. R. Levy. G6PD. Advances in Enzymology Related Areas and Molecular Biology 48, pp. 97-192, 1979
[4] H. Kirkman, E. Hendrickson. G6PD from Human erythrocytes. II. Subactive states of the enzyme from normal persons. Journal of Biological Chemistry 237, pp 2371-2376, 1962

[5] H. Kirkman. G6PD from Human Erythrocytes. I. Further purification and characterization. Journal of Biological Chemistry 237, pp 2364-2370, 1962

[6] G. W. Lohr, H.D. Waller, G6PD. In: Methods in Enzymatic Analysis Vol1, pp 673- 681 Edited by H.U. Bergmeyer Weinheim: Verlag Chemie GMBH, 1974

[7] M. Kanji, M. Toews, W. Carper. A kinetic study of G6PD. Journal of Biological Chemistry 251, pp 22582262, 1976

[8] D. Cappellini, G. Fiorelli. Glucose 6 Phosphate Dehydrogenase Deficiency. Lancet 371, pp 64-74, 2008

[9] A. E. Chung, R. C. Langdon. Human Erythrocyte G6PD. I. Isolation and properties of the enzyme. Journal of Biological Chemistry 238, pp 2309-2316, 1963

[10] E. Beutler. Red cell metabolism: A Manual of Biochemical Methods, pp 68-71, 1984

[11] J. D. Cronk. Pentose phosphate pathway. 2014. Available at: http://guweb2.gonzaga.edu/faculty/cronk/biochem/pindex.cfm?definition $=$ pentose phosphate pathway

[12] R. Mittler Oxidative stress, antioxidants and stress tolerance. TRENDS in Plant Science 7(9), pp 405-410, 2002

[13] S. Beydemir, M. Ciftci, O. Kufrevioglu. Purification and characterization of G6PD from sheep erythrocytes and inhibitory effects of some antibiotics on enzyme. Journal of Enzyme Inhibition and Medicinal Chemistry 4, pp 271-227, 2003

[14] R. Notaro, A. Afolayan, L. Luzzatto. Human mutations in Glucose-6-phosphate Dehydrogenase reflect evolutionary history. FASEB Journal 14, pp 485-494, 2000

[15] W. W. Cleland. Enzyme kinetics. Annual Review of Biochemistry 36(1), pp 77-112, 1967

[16] S. Singh, A. Anand, P. K. Srivastava. Regulation and properties of glucose-6-phosphate dehydrogenase: A review. International Journal of Plant Physiology and Biochemistry 4(1), pp 1-19, 2012

[17] M. Ciftci, A. Ciltas, O. Erdogan. Purification and characterization of glucose-6-phosphate dehydrogenase from rainbow trout (Oncorhynchus mykiss) erythrocytes. Veterinary Medicine - Czech 49(9), pp 327-333, 2004

[18] H. Levy, C. Cook. Purification and properties of NADP-linked G6PD from Acetobacter hansenii (Acetobacter xylinum) Archives of Biochemistry and Biophysics 291, pp 161-167, 1991

[19] F. Gleason. G6PD from Cyanobacterium Anabeana Spp Pcc 7120: Purification and kinetics of redox modulation. Archives of Biochemistry and Biophysic 334 (2), pp 277-283, 1996

[20] S. Banerjee, Fraenkel. Glucose-6-Phosphate Dehydrogenase from Escherichia coli and from a "High-Level" Mutant. Journal of Bacteriology, 110(1), pp 155-160, 1972 


\section{International Journal of Science and Research (IJSR) \\ ISSN (Online): 2319-7064 \\ Index Copernicus Value (2013): 6.14 | Impact Factor (2013): 4.438}

[21] R. Demoss, I. Gunsalus, R. Bard. G6PD in Leuconostoc mesenteroides. Journal of Bacteriology 66, pp 10-16, 1953

[22] C. Olive, M. Geroch, H. Levy. G6PD from Leuconostoc mesenteroides Kinetic studies. Journal of Biological Chemistry 246, pp 2047 - 2057, 1971

[23] D. Opheim, R. Bernlohr. Purification and regulation of G6PD from Bacillus licheniformis. Journal of Bacteriology 116(3), pp 1150-1159, 1973

[24] R. K. Scopes, V. Testolin, A. Stoter, K. GriffithsSmith, E. M. Algar. Simultaneous purification and characterization of glucokinase, fructokinase and glucose-6-phosphate dehydrogenase from Zymomonas mobilis. Biochemistry Journal 228(3), pp 627-634, 1985

[25] B. M. Anderson, C. D. Anderson. Purification and characterization of Azotobacter vinelandii Glucose-6phosphate Dehydrogenase: dual coenzyme specificity. Archives of Biochemistry and Biophysic. 321(1), pp 94-100, 1995

[26] B. Moritz, K. Striegel, A. A. De Graaf, H. Sahm. Kinetic properties of the glucose-6-phsophate dehydrogenase and 6-phosphogluconate dehydrogenases from Corynebacterium glutamicum and their application for predicting pentose phosphate pathway flux in vivo. European Journal of Biochemistry 267, pp 3442-3452, 2000

[27] T. Hansen, B. Schlichting, P. Schoneit. Glucose-6phosphate dehydrogenase from the hyperthermophilic bacterium Thermotoga maritima: expression of the g6pd gene and characterization of an extremely thermophilic enzyme. FEMS Microbiology Letters 216(2), pp 249-253, 2002

[28] J. R. Moustgaard. Purfication and characterization of isoforms of glucose 6-phosphate dehydrogenase associated with growth on $\mathrm{NO}_{3}$ from the green alga Chlamydomonas Reinhardtii. Thesis, Department of Biology, Queen's University Kingston, Ontario, Canada.

1998.

http://www.collectionscanada.gc.ca/obj/s4/f2/dsk2/ftp0 1/MQ36062.pdf

[29] K. Honjoh, A. Mimura, E. Kuroiwa, T. Hagisako, K. Suga, H. Shimizu, R. S. Dubey, T. Miyamoto, S. Hatano, M. Iio. Purification and characterization of two isoforms of glucose 6-phosphate dehydrogenase (G6PDH) from Chlorella vulgaris C-27. Bioscience Biotechnology \& Biochemistry 67(9), pp 1888-1896, 2003

[30] O. Ibraheem, I. O. Adewale, A. Afolayan. Purification and properties of glucose-6-phosphate dehydrogenase from Aspergillus aculeatus. Journal of Biochemistry and Molecular Biology 38, pp 584-590, 2005

[31] V. Jagannathan, P. Rangachari, M. Damodarran. Carbohydrate metabolism in citric acid fermentation, purification and properties of zwischenferment from A. niger. Biochemical Journal 64, pp 477-481, 1956

[32] M. Wennekes, T. Lambert, J. Peter, B. Vanden, W. Henk, Van Den Brook. Purification and characterization of Glucose-6-phosphate Dehydrogenase from Aspergillus niger and Aspergillus nidulans. Journal of General Microbiology 139, pp 2793-2800, 1993
[33] A. Malcolm, M, Shepherd. Purification and properties of Penicillium G6PD. Biochemical Journal 128, pp $817-831,1972$

[34] W. Niehaus, R. Dilts. Purification of G6PD from Aspergillus parasiticus. Archives of Biochemistry and Biophysics 228, pp 113-119, 1984

[35] W. A. Scott, E. L. Tatum. Purification and partial characterization G6PD from Neurospora crassa. Journal of Biological Chemistry 246, pp 6347-6352, 1971

[36] A. Tanaka, Y. Takenaka, M. Hirai, S. Fukui. G6PD and 6 - phosphogluconate Dehydrogenase of candida tropicalis. Partial purification and some properties. Agricultural Biology and Chemistry 40(9), pp 1829 1835,1976

[37] J. B. Hammond. G6PD from Agaricus bisporus: Purification and properties. Journal of General Microbiology 131, pp 321-328 1985

[38] F. Corpas, J. Barroso, L. Sandalio, S. Distefano, J Palma, J. Lupianez, L. Del Rio. A dehydrogenasemediated recycling system of NADPH in plant peroxisomes. Biochemistry Journal 330(7), pp $777-$ 784, 1998

[39] C. Schnarrenberger, A. Oeser, N. E. Tolbert. Two isoenzymes each of glucose-6-phosphate dehydrogenase and 6-phosphogluconate dehydrogenase in spinach leaves. Archive of Biochemistry and Biophysics 154(1), pp 438-448, 1973

[40] D. K. Srivastava, L.E. Anderson. Isolation and characterization of light- and dithiothreitolmodulatable glucose-6-phosphate dehydrogenase from pea chloroplasts. Biochimica Biophysica Acta 724, pp 359-369, 1983

[41] K. Fickensher, R. Schiebe. Purification and properties of the cytoplasm G6PD from pea leaves. Archives of Biochemistry Biophysic 24, pp 393-402, 1986

[42] J. S. Knight, M. J. Emes, P. M. Debnam. Isolation and characterisation of a fulllength genomic clone encoding a plastidic glucose 6-phosphate dehydrogenase from Nicotiana tobaccum. Planta 212(4), pp 499-507, 2001

[43] Y. Nemoto, T. Sasakuma. Specific expression of glucose-6-phosphate dehydrogenase (G6PDH) gene by salt stress in wheat (Triticum aestivum L.) Plant Science 158, pp 53-60, 2000

[44] Ka-Yu Law. Isolation and characterization of plastidic glucose-6-phosphate dehydrogenase (G6PDH) from Castor (Ricinus communis L.). Thesis, Department of Biology Queen's University Kingston, Ontario, Canada, 2007

[45] K. Graeve A. von Schaewen, R, Scheibe. Purification, characterization and cDNA sequence of glucose-6phosphate dehydrogenase from potato (Solanum tuberosum L.). The Plant Journal 5(3), pp 353-361, 1994

[46] C. Alban, J. Joyard, R. Douce. Comparison of glycerolipid biosynthesis in non-green plastids from sycamore (Acer pseudoplantanus) cells and cauliflower (Brassica oleracea) buds. Biochemical Journal 259, pp 775-783, 1989

[47] C. Alban, A-J. Dorne, J. Joyard, R. Douce. [I4C] Acetate incorporation into glycerolipids from cauliflower proplastids and sycamore amyloplasts. FEBS Letters 249, pp 95-99, 1989 


\section{International Journal of Science and Research (IJSR) \\ ISSN (Online): 2319-7064}

Index Copernicus Value (2013): 6.14 | Impact Factor (2013): 4.438

[48] E. O'Brien, B. Kurdi-Haidar, W. Wanachiwanawin, J. Carvajal, T. Villiamy, M. Cappadoro, P. Mason, L. Luzzatto. Cloning of the G6PD gene from Plasmodium falciparum. Molecular Biochemistry and Parasitology 64, pp 313, 1994

[49] J. B. Shatton, J. E. Halvie, S. Weinhouse. Glucose (Hexose 6-Phosphate) Dehydrogenase in Liver of Rainbow Trout*. The Biological Chemistry 246(15), pp 4878-4885, 1971

[50] H. ÖZDEMIR, V. TÜRKOGLU, M. ÇIFTÇI. Purification and Characterization of Glucose-6phosphate Dehydrogenase from Lake Van Fish (Chalcalburnus tarichii Pallas, 1811) Erythrocytes. Asian Journal of Chemistry 19(7), pp 5695-5702, 2007

[51] T. Berivan, N. N. Ulusu. Characterization of Glucose6-Phosphate Dehydrogenase Purified From Lamb Kidney Cortex.Turkish Journal of Biochemistry 30(2), pp 178-182, 2005

[52] M. Farnararo, F. Favilli, M. Tonelli, P. Bruni. Some properties of G6PD from rat and chick brain: A Comparative study. Comparative Biochemistry Physiology 61B, pp 351-356, 1978

[53] G. Yagil, F. Shimron, A. Hizi. On the mechanism of G6PD regulation in mouse liver. I. Characterization of the system. European Journal of Biochemistry 45, pp $189-200,1974$

[54] P. Ninfali, M. Ditroilo, S. Capellacci, E. Biagotti. Rabbit brain G6PD: biochemical properties and inactivation by free radical and 4-hydroxyl -2-nonenal. Neuro report 12(18), pp 45149-4153, 2001

[55] N. Ozer, C. Bilgi, O. Hamdi. Dog liver G6PD: Purification and kinetic properties. International Journal of Biochemistry and Cell Biology 34(3), pp 253-262, 2002

[56] M. Ciftci, S. Beydemir, H. Yilmaz, S. Altikat. Purification of G6PD from Buffalo (Bubalus bubalis) erythrocytes, and investigation of some kinetic parameters. Protein Experimental Purifications 29(2), pp 304-310, 2003

[57] S. Gezici, G. F. Domagk. G6PD from Bovine erythrocytes: kinetic properties and the electrophoresis comparison of its subunit structure with G6PDH from other sources. International Journal of Biochemistry 10, pp 427-432, 1979

[58] V. Bayazit, M. K. Cayci, K. M. Khan. Purification and Kinetic Properties of Glucose-6-Phosphate dehydrogenase from Goat (Cpraaegagrus hicrus) Erythrocytes. Journal of Chemical Society Pakistan 27(5), pp 518-526, 1995

[59] A. Yoshida. G6PD. I. Purification and characterization of normal (B+) enzyme. Journal of Biological Chemistry 241, pp 4966 - 4976, 1966

[60] P. Cohen, M. Rosemeyer. Human G6PD: purification of the Erythrocyte enzyme and the influence of Ions on its activity. European Journal of Biochemistry 8, pp 17, 1969

[61] A. Afolayan, L. Luzzatto. Genetic variants of human erythrocyte Glucose-6-phosphate Dehydrogenase. I. Regulation of activity by oxidized and reduced Nicotinamide Adenine Dinucleotide Phosphate (NADP+). Biochemistry 10, pp $415-419,1971$
[62] O. Babalola, R. Cancedda, L. Luzzatto. Genetic variants of G6PD from human erythrocyte: unique properties of A- variant isolated from deficient cells Proceedings of National Academy of Science (USA) 69, pp 946-950, 1972

[63] A. Kahn, J. C. Dreyfus. Purification of G6PD from red blood cells from human leukocytes. Description of a new method of purification by Electric elution of the enzyme with NADP + . Biochemica Biophysica Acta 334, pp 257-265, 1974

[64] L. Carmadella, C. Caruso, B. Rutigliano, M. Romano, G. Diprisco, F. Descalzi-Cancedda. Human erythrocyte G6PD. Identification of a reactive lysyl residue labeled with pyridoxal 5/ phosphate. European Journal of Biochemistry 177, pp 485-489, 1988

[65] O. Warburg, W. Christian. Über Aktivierung der robin sonschem Hexosemono -phosporsäure in rotten Blutzellen and the Gewinnung aktvierender fermentlÖsung. Biochemistry (Z) 242, pp 206 - 227, 1931

[66] A. Yoshida. Enzyme purification by selective Elution with substrate analog from Ion-exchange columns: Application to G6PD, pseudocholinesterase, lactate dehydrogenase and Alanine dehydrogenase. Analytical Biochemistry 37, pp 357-367, 1970

[67] D. Wright, H. Huppe, D. Turpin. Invivo and invitro studies of G6PD from Barley root plastids in relation to reductant supply for NO2 - Assimilation. Plant Physiology 114(4), pp 1413-1417, 1997

[68] K. Graeve, A. von Schaewen, R. Scheibe. Purification, characterization and cDNA sequence of glucose-6phosphate dehydrogenase from potato (Solanum tuberosum L.). The Plant Journal 5(3), pp 353-361, 1994

[69] N. N. Ulusu, B. Tandogan, F. E. Tezcan. Kinetic properties of glucose-6-phosphate dehydrogenase from lamb kidney cortex. Biochimie 87, pp 187-190, 2005

[70] S. Ragunathan, H. R. Levy. Purification and Characterization of the NAD-preferring glucose-6phosphate dehydrogenase from Acetobacter hansenii (Acetobacter xylinum). Archives Biochemistry and Biophysics 310(2), pp 360-366, 1994

[71] C. Olive, M. E. Geroch, H. R. Levy. Glucose-6phosphate dehydrogenase from Leuconostoc mesenteroides. Journal of Biology and Chemistry 246(7), pp 2047-2057, 1971

[72] R. Tabita, D. G. Lundgren. Glucose-6-phosphate dehydrogenase from the chemolithotroph Thiobacillus ferrooxidan. Journal of Bacteriology 108, pp 343-352, 1971

[73] B. M. Anderson, D. J. Wise, C. D. Anderson. Azotobacter vinelandii glucose-6-phosphate dehydrogenase properties of NAD- and NADP linked reactions. Biochimica et Biophysica Acta 1340, pp 268-276, 1997

[74] T. Hansen, B. Schlichting, P. Schoneit. Glucose-6phosphate dehydrogenase from the hyperthermophilic bacterium Thermotoga maritima: expression of the g6pd gene and characterization of an extremely thermophilic enzyme. FEMS Microbiology Letters 216(2), pp 249-253, 2002 


\section{International Journal of Science and Research (IJSR) \\ ISSN (Online): 2319-7064}

Index Copernicus Value (2013): 6.14 | Impact Factor (2013): 4.438

[75] A. V. Semenikhina, T. N. Popova, L. V. Matasova. Catalytic properties of glucose-6-phosphate dehydrogenase from pea leaves. Biochemistry (Moscow) 64(8), pp 863-866, 1999

[76] A. Danisan, D. Ceyhan, I. H. Ogus, N. Ozer. Purification and characterization of glucose-6phosphate dehydrogenase from rat small intestine. Protein Journal 23(5), pp 317-324, 2004

[77] H. Yilmaz, M. Ciftci, S. Beydemir, E. Bakan. Purification of G6PD from chicken erythrocytes: Investigation of some kinetic properties. Preparative Biochemistry and Biotechnology 32(3), pp 287 - 301, 2002

[78] M. Persico, G. Vigelietto, G. Martini, D. Toniolo, G. Paonessa, C. Moscatelli, R. Dono, T. Vulliamy, L. Luzzatto, M. D'urso. Isolation of human G6PD cDNA 98 clones: primary structure of the protein and unusual $5^{\text {ee }}$ non-coding region. Nucleic Acid Research 14, pp $2511-2522,1986$

[79] T. Takizawa, I-Yih. Huang, T. Ikuta, A. Yoshidat. Human glucose-6-phosphate dehydrogenase: Primary structure and cDNA cloning (oligonucleotide probe/amino acid sequence/X chromosome). Proceedings National Academy of Science (USA) 83, pp 4157-4161

[80] P. Rowland, A. K. Basak, S. Gover, H. R. Levy, M. J. Adams. The three-dimensional structure of glucose 6phosphate dehydrogenase from Leuconostoc mesenteroides refined at $2.0 \AA$ resolution. Structure 2, pp 1073-1087, 1994

[81] L. Carmadella, C. Caruso, B. Rutigliano, M. Romano, G. Diprisco, F. Descalzi-Cancedda. Human erythrocyte G6PD. Identification of a reactive lysyl residue labeled with pyridoxal 5/ phosphate. European Journal of Biochemistry 177, pp 485-489, 1988

[82] A. Yoshida. Micro method for determination of Blocked NH2 - Terminal amino acid of protein: Application to identification of Acetylserine of phosphoglycerate kinase and pyroglutamic acid of Glucose-6 phosphate dehydrogenase. Analytical Biochemistry 49, pp $320-325,1972$

[83] H. R. Levy. The interaction of mammary G6PD with pyridine nucleotides and 3/3 hydroxyandroste-5-en-17one. Journal of Biological Chemistry 238, pp 775-784, 1963

[84] M. Rattazzi. Isolation and purification of Human Erythrocyte G6PD form small amounts of Blood. Biochimica Biophysica Acta 181, pp 1-11, 1969

[85] W. T. Lee, T. G. Flynn, C. Lyons, H. R. Levy. Cloning of the gene and amino acid sequence for G6PD from Leuconstoc mesenteroides. Journal of Biological Chemistry 266, pp 13028-1304, 1991

[86] D. Rowley, R. Wolf. Molecular characteriszation of the Escherichia coli K - 12 zwf gene encoding G6PD. Journal of Bacteriology 173, pp 968 - 977, 1991

[87] I. Nogae, M. Johnson. Isolation and characterization of the zwfi gene of Saccharomyces cerevisiae, encoding G6PD. Gene 96, pp 161-169, 1990

[88] Y-S. HO, A. J. Howard, J. D. Crapo. Cloning and sequencing of a DNA encoding rat G6PD. Nucleic Acid Research 16, 7746, 1988
[89] D. Toniolo, M. Fullippi, R. Dono, T. Lettieri, G. Martini. The $\mathrm{CpG}$ island in the 51 - region of the G6PD gene of man and mouse. Gene 102, pp 197-203, 1991

[90] H. Engel, W. Domschke. M. Albert, G. Domagk. Protein structure and enzymatic activity. Purification and properties of a crystalline G6PD from Candida utilis. . Biochemica Biophysica Acta 191, pp 509-516, 1969

[91] R. Chilla, K. M. Doering, G. F. Domagk, M. Rippa. A simplified procedure for the isolation of a highly active crystalline G6PD from Candida utilis. Archives of Biochemistry and Biophysics 159, pp 235-239, 1973

[92] I. Nogae, M. Johnson. Isolation and characterization of the zwfi gene of Saccharomyces cerevisiae, encoding G6PD. Gene 96, pp 161-169, 1990

[93] W. E. Criss, K. W. Mckerns. Purification characterization of G6PD from cow Adrenal cortex Biochemistry I, pp 125-134, 1968

[94] A. Hizi, G. Yagil. On the mechanism of G6PD. Regulation in mouse liver.2. Purification and properties of the mouse liver enzyme. European Journal of Biochemistry 45, pp 201-209, 1974

[95] P. J. Mason. New insights into G6PD deficiency. British Journal of Haematology 94, pp 585-591, 1996

[96] C. Naylor, P. Rowland, A. Basak, S. Gover, P. Mason, J. Bautista, T. Vulliiamy, L. Luzzatto, M. Adams. G6PD Mutations causing Enzyme Deficiency in a model of the Tertiary structure of human enzyme. Blood 87(7), pp 2974-2982, 1996

[97] S. W. N. Au, S. Gover, V. M. Lam, M. J. Adams. Human glucose-6-phosphate dehydrogenase: the crystal structure reveals a structural NADP + molecule and provides insights into enzyme deficiency. Structure 8, pp 293-303, 2000

[98] M. Kotaka, S. Gover, L. Vacndeputte-Rutten, S. W. N. $\mathrm{Au}$, V. M. S. Lam, M. J. Adams. Structural studies of glucose-6-phosphate and NADP+ binding to human glucose-6-phosphate dehydrogenase. Acta Crystallography 61, pp 495-504, 2005

[99] A. Afolayan. The essential cysteine of Candida utilis Glucose-6-phosphate Dehydrogenase. Nigeria Journal of Natural Science 4, pp 61-65, 1989

[100]A. Yoshida, V. Hoagland. Active molecular unit and NADP+ content of Human G6PD. Biochemical Biophysical Research Communication 40, pp 1167 1172. 1970

[101]M. J. Wennekes, T. G. Lambert, J.M. Peter, V. B. Henk, W.J. Van Den Brook Purification and characterization of Glucose-6-phosphate Dehydrogenase from Aspergillus niger and Aspergillus nidulans. Journal of Genenal Microbiology 139: 27932800, 1993

[102]C. Naylor, S. Gover, A. Basak, M. Cosgrove, H. Levy, M. Adams. NADP+ and NAD + binding to the dual coenzyme specific enzyme Leuconostoc mesenteroides G6PD: different interdomain hinge angles are seen in different binary and ternary complexes. Acta of Crystallography and Biological Crystallography 57(pt5), pp 635-648, 2001 


\section{International Journal of Science and Research (IJSR) \\ ISSN (Online): 2319-7064}

Index Copernicus Value (2013): 6.14 | Impact Factor (2013): 4.438

[103]A. Yoshida. Change of Activity and substrate specificity of Human G6PD by oxidation. Archives of Biochemistry and Biophysics 159, pp $82-88,1973$

[104]F. Gomez-Gallego, A. Garrido-Pertierra, J. M. Bautista. Structural defects underlying protein dysfunction in human glucose-6-phosphate dehydrogenase A(-) deficiency. Journal of Biology and Chemistry 275, pp 9256-9262, 2000

[105]X. T. Wang, T. F. Chan, V. M. S. Lam, P. C. Engel. What is the role of the second "structural" NADP+binding site in human glucose 6-phosphate dehydrogenase? Protein Science 17, pp 1403-1411, 2008

[106]H. R. Levy. G6PD from Leuconostoc mesenteroides . Biochemical Society Transactions 17, pp 313-315, 1989

[107]L. Luzzatto, G. Battistuzzi. Glucose-6-phosphate Dehydrogenase. Advances in Human Genetics 14, pp 217-329, 1985

[108]V. H. Cheldelin. Dual nucleotide specificity of A. Suboxydans and A. Vinelandii, in: Metabolic Pathways in Microorganisms. Wiley New York, pp 201-217, 1961

[109]R. D. Demoss, I. C. Gunsalus, R. C. Bard. G6PD in Leuconostoc mesenteroides. Journal of Bacteriology 66, pp 10-16, 1953

[110]R. Reuter, P. Metz, G. Lorenz, G. Kopperschlager. Interaction of bacterial G6PD with triazine dyes: a study by means of affinity partioning and kinetic analysis. Biomedica Biophysica Acta 49, pp 151 - 160, 1990

[111]L. P. Stabile, D. L. Hodge, S. A. Klautky, L. M. Salati. Post transcriptional regulation of glucose-6-phosphate dehydrogenase by dietary polyunsaturated fat. Archive of Biochemistry and Biophysics 332, pp 269-279, 1996

[112]H. Tao, W. Szeszel-Fedorowicz, B. Amir-Ahmady, M. A. Gibson, L. P. Stabile, L. M. Salati. Inhibition of the splicing of glucose-6-phosphate dehydrogenase precursor mRNA by polyunsaturated fatty acids. Journal of Biology and Chemistry 277, pp 3127031278, 2002

[113]R. F. Kletzien, P. K. Harris, L. A. Foellmi. Glucose-6phosphate dehydrogenase: a "housekeepinge enzyme subject to tissue specific regulation by hormones, nutrients and oxidant stress. FABES Journal 8, pp 174181,1994

[114]K. Yoshimoto, T. Nakamura, A. Ichihara. Reciprocal effects of epidermal growth factor on key lipogenic enzymes in primary cultures of adult rat hepatocytes. Journal Biology Chemistry 258, pp 12355-12361, 1983

[115]H. G. Zimmer, B. Lankat-Butlgereit, C. KolbeckRuhmkorff, T. Nagano, W. Zierhut. Effects of norepinephrine on the oxidative pentose phosphate pathway in the rat heart. Circulation research 71, pp 451-459, 1992

[116]L. B. Nasr, J.D. Monet, P. Lucas, C.A. Bader. Vitamin D3 and glucose-6-phsophate dehydrogenase in rat duodenal epithelial cells. American journal of Physiology 193, pp G760-G765, 1989

[117]D. J. Stumpo, R. F. Kletzien. The effect of ethanol, alone and in combination with the glucocorticoids and insulin, on glucose-6-phosphate dehydrogenase synthesis and mRNA in primary cultures of hepatocytes. Biochemistry Journal 226, pp 123-130, 1985

[118]T. Fahrendorf, W. Ni, B. S. Shorrosh, R. A. Dixon Stress responses in alfalfa (Medicago sativa L.) XIX. Transcriptional activation of the oxidative pentose phosphate pathway genes at the onset of the isoflavinoid phytoalexin response. Plant Molecular Bioliogy 28, pp 885-900, 1995

[119]R. Hauschild, A. von Schaewen. Differential regulation of glucose-6-phosphate dehydrogenase isoenzymes activities in potato. Plant Physiology 133, pp 47-62, 2003

[120]D. Miethe, W. Babel. Regulation of glucose-6phosphate dehydrogenase in the obligate methyltrophic bacterium Pseudomonas W6. Z. Allg. Mikrobiology 16, pp 289-299, 1976

[121]R. A. Steinbach, H. Sahm, H. Schutte. Purification and regulation of glucose-6-phosphate dehydrogenase from obligate methanol utilizing bacterium Methylomonas M15. European Journal of Biochemistry 87, pp 409415, 1978

[122]N. Ozer, Y. Aksoy, I. Ogus. Kinetic properties of human placental G6PD. International Journal of Biochemistry and Cell Biology 33(3), pp 221-226, 2001

[123]L. Glaser, D. H. Brown. Purification and properties of G6PD. Journal of Biological Chemistry 216, pp 67-79, 1955

[124]T. Villiamy, M. Deurso, G. Battistuzzi, M. Estrada, N. Foulks, G. Martini, V. Calabro, V. Poggi, R. Giodono, M. Town, L. Luzzatto, M. Persico. Diverse point mutations in the human G6PD, gene cause enzyme deficiency and mild or serve hemolytic anaemia. Proceedings of National Academy of Science (USA) 85, pp 5171-5175, 1988

[125]E. Beutler. G6PD Deficiency, Blood 84, pp 3613-3636, 1994

[126]P. Madvig, S. Abraham. Enzyme activities during development of some organs of the rat. Journal of Nutrition 110, pp 100-104, 1980

[127]R. L. Baldwin, Y. T. Yang. In lactation, A Comprehensive Treatise Vol. 1,B.L. Larson and V.R. Smith. Eds. Academic press. New York pp 349-411, 1974

[128]S. Backstrom. Activation of Glucose-6-phosphate Dehydrogenase in sea urchin embryos of different developmental. Trends in Experimental cellular Research. 18, pp $347-356,1959$

[129]T. Yamauchi, E. Goldberg. A synchronous expression of G6PD in splake trout embryos. Developmental Biology 39, pp $63-68,1974$

[130]K. Tsai, I. Hung, C. Chow, A. Stern, S. Chao, D. Chiu. Impaired production of nitric oxide, super oxide and hydrogen peroxide in G6PD deficient granulocytes. FEBS Letters 436, pp 411 - 414, 1998

[131]L. Luzzatto, A. Afolayan. Enzymic properties of different types of human erythrocyte G6PD, with characterization of two new genetic variants. Journal of Clinical Investigation 47(8), pp 1833-1841, 1968 


\section{International Journal of Science and Research (IJSR) \\ ISSN (Online): 2319-7064}

Index Copernicus Value (2013): 6.14 | Impact Factor (2013): 4.438

[132]P. Arese, A. Flora. Pathophysiology of Hemolysis in Glucose-6-phosphate Dehydrogenase Deficiency. Seminars in Hematology. 27, pp 1-30, 1990

[133]M. Kaplan, C. Hammerman. G6PD deficiency: a potential source of severe neonatal hyperbilirubinaemia and kernicterus. Seminars in Neonatology 2, pp 121128,2002

[134]T. Meloni, G. Forteleoni, A. Dore, S. Cutillo. Favism and hemolytic anemia in glucose-6-phosphate dehydrogenase-defi cient subjects in North Sardinia. Acta Haematology 70, pp 83-90, 1983

[135]M. S. A. Tango, Islam M. R. Potential of Extremophiles for Biotechnological and Petroleum Applications. Energy Sources 24, pp 543-559, 2002

[136]B. van-den-Burg. Extremophiles as a source for novel enzymes. Current Opinion in Microbiology 6, pp 213218,2003

[137]D. A. Otohinoyi, O. Ibraheem. Prospecting microbial extremophiles as valuable resources of biomolecules for biotechnological applications. International Journal of Science and Research 4(1), pp 1042-1059, 2015

[138]F. H. Lojudice, D. P. Silva, N. I. T. Zanchin, C. C. Oliveira, A. Pessoa. Overexpression of glucose-6phosphate dehydrogenase in genetically modified Saccharomyces cerevisiae. Applied Biochemistry and Biotechnology 91-93(1-9), pp 161-169, 2001

[139]M. A. Souza, M. Z. Ribeiro, D. P. Silva, A. Pessoa Jr., M. Vitolo. Effect of $\mathrm{pH}$ on the stability of hexokinase and glucose 6-phosphate dehydrogenase. Applied Biochemistry and Biotechnology 98-100 (1-9), pp 265272, 2002

[140]Y. Chisti. Fermentation (Industrial). (1999)Available at: http://www.massey.ac.nz/ ychisti/FermentInd.PDF

[141]L. Alba-Lois, C. Segal-Kischinevzky. Yeast Fermentation and the Making of Beer and Wine. Nature Education 3(9), pp 17, 2010

[142]D. Wu, Q. Zhai, X. Shi. Alcohol-induced oxidative stress and cell responses. Journal of Gastroenterology and Hepatology 3, pp S26-S29, 2006

[143]D. Wu, A. I. Cederbaum. Alcohol, Oxidative Stress, and Free Radical Damage. 2004. Available at: http://pubs.niaaa.nih.gov/publications/arh27-4/277284.htm

[144]O. B. Akpor, D. A. Otohinoyi, T. D. Olaolu, B. I. Aderiye. Pollutants in Wastewater Effluents: Impacts and Remediation Processes. International Journal of Environmental Research and Earth Science 3(3), pp 5059,2014

[145]D. A. Otohinoyi, O. Ekpo, O. Ibraheem. Effect of ambient temperature storage on 2,2-diphenyl-1picrylhydrazyl (DPPH) as a free radical for the evaluation of antioxidant activity. International Journal of Biological and Chemical Science 8(3), pp 12621268,2014

[146]O. Tsydenova, V. Batoev, A. Batoeva. Solar-Enhanced Advanced Oxidation Processes for Water Treatment: Simultaneous Removal of Pathogens and Chemical Pollutants. International Journal of Environment and Public Health 12(8), pp 9542-9561, 2015
[147]Navigant Research. 2013. Available at https:/www.navigantresearch.com/research/marketdata-hydrogen-infrastructure

[148]J. Woodward, M. Orr, K. Cordray, E. Greenbaum. Biotechnology: Enzymatic production of biohydrogen. Nature 405, pp 1014-1015, 2000

[149]J. R. Simons, M. Mosisch, A. E. Torda, L. Hilterhaus. Site directed immobilization of glucose-6-phosphate dehydrogenase via thiol-disulfide interchange: influence on catalytic activity of cysteines introduced at different positions. Journal of Biotechnology 167(1), pp $1-7,2013$

[150]F. Yoshinaga, N. Tonouchi, K. Watanabe. Research progress in production of bacterial cellulose by aeration and agitation culture and its application as a new industrial material. Bioscience Biotechnology \& Biochemistry 61, pp 219-224, 1997

[151]J. Scharte, H. Schön, Z. Tjaden, E. Weis, A. von Schaewen. Isoenzyme replacement of glucose-6phosphate dehydrogenase in the cytosol improves stress tolerance in plants. Proceddings of National Academiy of Science 106(19), pp 8061-8066, 2009

[152]E. Tsouko, A. S. Khan, M. A. White, J. J. Han, Y. Shi, F. A. Merchant, M. A. Sharpe, L. Xin, D. E. Frigo. Regulation of the pentose phosphate pathway by an androgen receptor-mTOR-mediated mechanism and its role in prostate cancer cell growth 3, pp e103, 2014; doi:10.1038/oncsis. 2014.18

\section{Authors Profile}

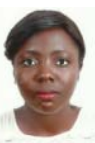

Arolasafe Gbemisola $\mathbf{J}$. is an extraordinarily brilliant first class graduate of Biochemistry BSc. (Hons) Degree from Landmark University, Omu Aran, Nigeria. She is currently a postgraduate student in Biomedical Informatics at Nova South Eastern University, Fort Lauderdale, Florida, USA.

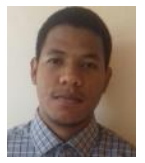

Otohinoyi David A. graduated from Landmark University with BSc. (Hons) Degree in Biochemistry. $\mathrm{He}$ is currently a Medical student at All Saints University School of Medicine, Roseau, Dominica. He is a member of Science Association of Nigeria and Nigeria Society of Experimental Biologist.

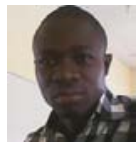

Mr Jeje Temitope O. is an Assistant Lecturer in the Department of Biochemistry, Federal University OyeEkiti, Nigeria. He holds MTech. Biochemistry from Federal University of Technology, Akure, Nigeria. His area of specialization is Medical Biochemistry and he is a member of many Scientific Associates among which are Biotechnology Society of Nigeria and Science Association of Nigeria.

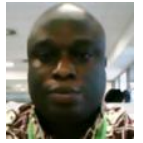

Dr Ibraheem Omodele is a Senior Lecturer in the Department of Biochemistry, Federal University OyeEkiti, Nigeria. Currently his research interests are in the areas of Enzyme and Natural Products Technologies, Plant Stress and Signaling Responses and Phytomedicine. He is a member of a number of academic societies, among which are the prestigious Royal Society of South Africa, South Africa Society of Microbiology and Biotechnology Society of Nigeria. 